\title{
Dissolved carbonate and pH control the dissolution of uranyl phosphate minerals in flow-through porous media
}

\author{
Estela REINOSO-MASET ${ }^{\mathrm{a}, \mathrm{b}, *}$, Nicolas PERDRIAL $^{\mathrm{c}}$, Carl I. STEEFEL $^{\mathrm{d}}$, \\ Wooyong $\mathrm{UM}^{\mathrm{e}, \mathrm{f}}$, Jon CHOROVER ${ }^{\mathrm{g}}$, Peggy A. O’DAY ${ }^{\mathrm{h}, \mathrm{a}}$ \\ ${ }^{a}$ Sierra Nevada Research Institute, University of California Merced, \\ 5200 North Lake Road, Merced, CA 95343, USA \\ ${ }^{\mathrm{b}}$ Centre for Environmental Radioactivity CoE, Faculty of Environmental Sciences and Natural Resource \\ Management, Norwegian University of Life Sciences, 1432 Aas, Norway \\ ${ }^{\mathrm{c}}$ Department of Geology, University of Vermont, \\ 180 Colchester Ave., Burlignton, VE 05405, USA \\ ${ }^{\mathrm{d}}$ Energy Geosciences Division, Lawrence Berkeley National Laboratory, \\ 1 Cyclotron Road, M.S. 74R316C, Berkeley, CA 94720, USA \\ ${ }^{\text {e }}$ Energy and Environment Directorate, Pacific Northwest National Laboratory, \\ 902 Battelle Blvd., P7-54, Richland, WA 99354, USA \\ ${ }^{\mathrm{f}}$ Division of Advanced Nuclear Engineering, Pohang University of Science and Technology (POSTECH), Pohang, \\ South Korea \\ g Department of Environmental Science, University of Arizona, \\ 177 E. Fourth St., Tucson, AZ 85721, USA \\ ${ }^{\mathrm{h}}$ Life and Environmental Sciences Department, School of Natural Sciences, University of California Merced, \\ 5200 North Lake Road, Merced, CA 95343, USA \\ *Correspondence to: estela.reinoso.maset@nmbu.no
}

\author{
Environmental Science and Technology \\ April 2020 \\ http://dx.doi.org/10.1021/acs.est.9b06448
}

Number of Pages: 36

Number of Tables: 8

Number of Figures: 9 


\section{Table of Contents}

S1. Synthesis of Uranyl Phosphate Minerals _______________________________________ 3

S2. Flow-Through Column Experiments______________________________________ 4

S2.1 Input Solutions _____________________ 4

Table S1. Salts and recipe concentrations, targeted elemental concentrations, and measured composition and $\mathrm{pH}$ of synthetic background porewater (BPW)

S2.2 Experimental Transport and Physical Properties__________ 5

Table S2. Experimental conditions for K-ankoleite, Na- and Ca-autunite dissolution flow-through columns _ 5

Figure S1. Representative Br conservative tracer breakthrough curves ___ 6

S3. Effluent Solutions Analyses _____________________________________ 7

S3.1 Analytical Methodology ___ _ 7

S3.2 Effluent Solutions Results________ 8

Figure S2. Concentration of effluent $\mathrm{Na}, \mathrm{Mg}, \mathrm{K}, \mathrm{Ca}, \mathrm{Cl}^{-}, \mathrm{SO}_{4}{ }^{2-}$, dissolved total carbon (TC) and $\mathrm{pH}$

S4. Solid Phase Characterization ____________________________________

S4.1 Analytical and Spectroscopy Methodology _______ 9

S4.2 Mineral Phase Characterization Results________ 12

S4.2.1 General Characteristics______ 12

Unreacted Minerals _______ 12

FTIR and Raman Spectra and Band Assignment_____ 13

Minerals After Reaction ____ 14

Figure S3. SEM images of synthetic K-ankoleite, Na-autunite, Ca-autunite, chernikovite and quartz minerals 16

Table S3. Characterization of K-ankoleite, Na-autunite, Ca-autunite and chernikovite synthetic minerals _ 17

Figure S4. FTIR and Raman spectra ___ 18

Table S4. Assignment of vibration bands

S4.2.2 X-ray Diffraction Before and After Reaction ___ 20

Table S5. Quantitative results (in \%) of Rietveld simulations__ 20

Figure S5a. X-ray diffractograms of quartz and reference minerals __ 21

Figure S5b. Crystal structures of uranyl phosphate minerals___ 22

S4.2.3 X-ray Absorption Spectroscopy Before and After Reaction _____ 23

Unreacted Minerals Shell-by-Shell Fits ____ 23

Table S6. Uranium $\mathrm{L}_{\mathrm{III}}$-edge EXAFS shell-by-shell fits for unreacted K-ankoleite, Na-autunite, Ca-autunite and chernikovite _ 24

Figure S6. Deconvolution of single- and multi-scattering (MS) paths of $\mathrm{U}_{\mathrm{III}}$-edge EXAFS spectra and Fourier

Transforms (FT) _ 25

Reacted Minerals Linear Combination and Shell-by-Shell Fits ___ 26

Table S7. U LIII-edge EXAFS linear combination and shell-by-shell fits for reacted K-ankoleite, Na-autunite and Ca-autunite 26

Figure S7. Deconvolution of single- and multi-scattering (MS) paths of U LIII-edge EXAFS spectra and Fourier Transforms (FT) _ 28

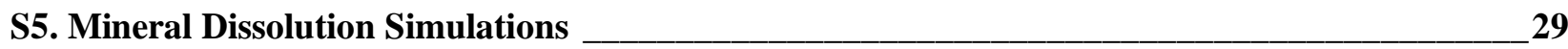

S5.1 Reactive Transport Modeling ___ 29

S5.2 Thermodynamic Database_______ 31

Table S8. Main thermodynamic solution and solid phase chemical equilibria __ 31

S5.3 Simulation of Effluent Solutions _____ 34

Figure S8. Reactive transport simulation of dissolved total carbon (TC) concentration and $\mathrm{pH}$ 


\section{S1. Synthesis of Uranyl Phosphate Minerals}

Uranyl minerals were synthesized following a methodology adapted from Wellman, et al. ${ }^{1}$ and Gudavalli, et al. ${ }^{2}$. An initial $200 \mathrm{~mL}$ solution was prepared using a 1:1 v/v ratio of 0.11 $\mathrm{M}$ uranyl nitrate $\left(\mathrm{UO}_{2}\left(\mathrm{NO}_{3}\right)_{2} \cdot 6 \mathrm{H}_{2} \mathrm{O}\right.$; Spectrum Chemicals, USA) and $1.1 \mathrm{M}$ phosphoric acid $\left(\mathrm{H}_{3} \mathrm{PO}_{4}\right.$; Aldrich Chemicals, USA) aqueous solutions (ultrapure water, $18.2 \mathrm{M} \Omega \cdot \mathrm{cm}$, EASYpure UV, Barnstead Thermolyne), stirred for $30 \mathrm{~min}$ at room temperature and aged for $5 \mathrm{~d}$. The crystalline, bright lemon-yellow product that precipitated (chernikovite, $\left.\mathrm{H}\left[\left(\mathrm{UO}_{2}\right)\left(\mathrm{PO}_{4}\right)\right] \cdot n \mathrm{H}_{2} \mathrm{O}\right)$ was vacuum filtered (0.22 $\mu \mathrm{m}$ Type GS Millipore Membrane filters), rinsed with a few $\mathrm{mL}$ of ultrapure water and air dried before storage in capped glass vials (4$6 \mathrm{~mL}$ clear glass threated vials with caps and PTFE-faced rubber liner; Firsherbrand Fisher Scientific) away from sunlight. New precipitate formed after $2 \mathrm{~d}$ thus was separated by filtration, rinsed, air dried and homogenized with the first products. Subsequently, the filtrated solution (still containing excess dissolved $\mathrm{U}$ ) was divided in three $50 \mathrm{~mL}$ and each was mixed with $50 \mathrm{~mL}$ of $0.1 \mathrm{M} \mathrm{KOH}, \mathrm{NaOH}$ or $\mathrm{CaCl}_{2}$ (ACS reagents from Fisher Chemicals, J.T Baker and Acros Organics, USA) in order to obtain K-ankoleite, $\left(\mathrm{K}_{2}\left[\left(\mathrm{UO}_{2}\right)\left(\mathrm{PO}_{4}\right)\right]_{2} \cdot n \mathrm{H}_{2} \mathrm{O}\right)$, Na-autunite $\left(\mathrm{Na}_{2}\left[\left(\mathrm{UO}_{2}\right)\left(\mathrm{PO}_{4}\right)\right]_{2} \cdot n \mathrm{H}_{2} \mathrm{O}\right)$ and Ca-autunite, $\left(\mathrm{Ca}\left[\left(\mathrm{UO}_{2}\right)\left(\mathrm{PO}_{4}\right)\right]_{2} \cdot n \mathrm{H}_{2} \mathrm{O}\right)$ minerals, respectively. After a gentle swirl, instant precipitation of bright green-yellow products occurred for the $\mathrm{U}+\mathrm{KOH}$ and $\mathrm{U}+\mathrm{NaOH}$ solutions.

Precipitates in the $\mathrm{U}+\mathrm{CaCl}_{2}$ solution formed at a slower rate. In all cases, the solutions were left to age for $4 \mathrm{~d}$ at room temperature without stirring and the precipitates were collected in the same manner as for chernikovite. Filtered solutions were let to stand for longer time and the newly formed precipitates were collected after 5 and $19 \mathrm{~d}$. Air dried products were homogenized, and between 0.4 and $1.3 \mathrm{~g}$ were obtained for each mineral. The combined reaction yield with respect to initial uranyl nitrate mass was $\sim 70 \%$. 


\section{S2. Flow-Through Column Experiments}

\section{S2.1 Input Solutions}

The composition of a $\mathrm{NO}_{3}$-free background porewater (BPW) solution relevant to a site of $\mathrm{U}$ contamination ${ }^{3}$, the DOE's Hanford site, but also typical of freshwater aquifer systems was chosen as the 'low carbonate BPW' for the dissolution experiments (Table S1). Although nitrate can be present as co-contaminant at some sites, additional complicating processes, e.g., possible nitrate reduction if the columns became sub-oxic or potential complexation with uranyl, were not the focus of this study. To produce a BPW of higher carbonate concentration (referred herein as the 'high carbonate BPW'), chloride salts in the preparation recipe were substituted for carbonate salts (Table S1). The day before starting the experiments, input solutions were prepared in $3 \mathrm{~L}$ acid-washed glass bottles using analytical grade reagents and ultrapure water (18.2 M $\Omega \cdot \mathrm{cm}$; EASYpure UV, Barnstead Thermolyne or Milli-Q Direct 16, EDM Millipore), equilibrated with air, and sealed parafilm (which was also used to hold the column tubing in place during the experiment). The parafilm cover was removed occasionally for short periods of time for sampling the input solutions and measure the element concentrations and pH (Table S1), which were considered as the actual input solutions' composition used in the reactive transport modelling.

Table S1. Salts and recipe concentrations, targeted elemental concentrations, and measured composition and $\mathrm{pH}$ of synthetic background porewater (BPW) used as input solutions in the uranyl phosphate minerals flow-through column experiments.

\section{Recipe concentrations $\left(\mathrm{mg} \mathrm{L} \mathbf{~}^{-1}\right)$}

Low BPW High BPW

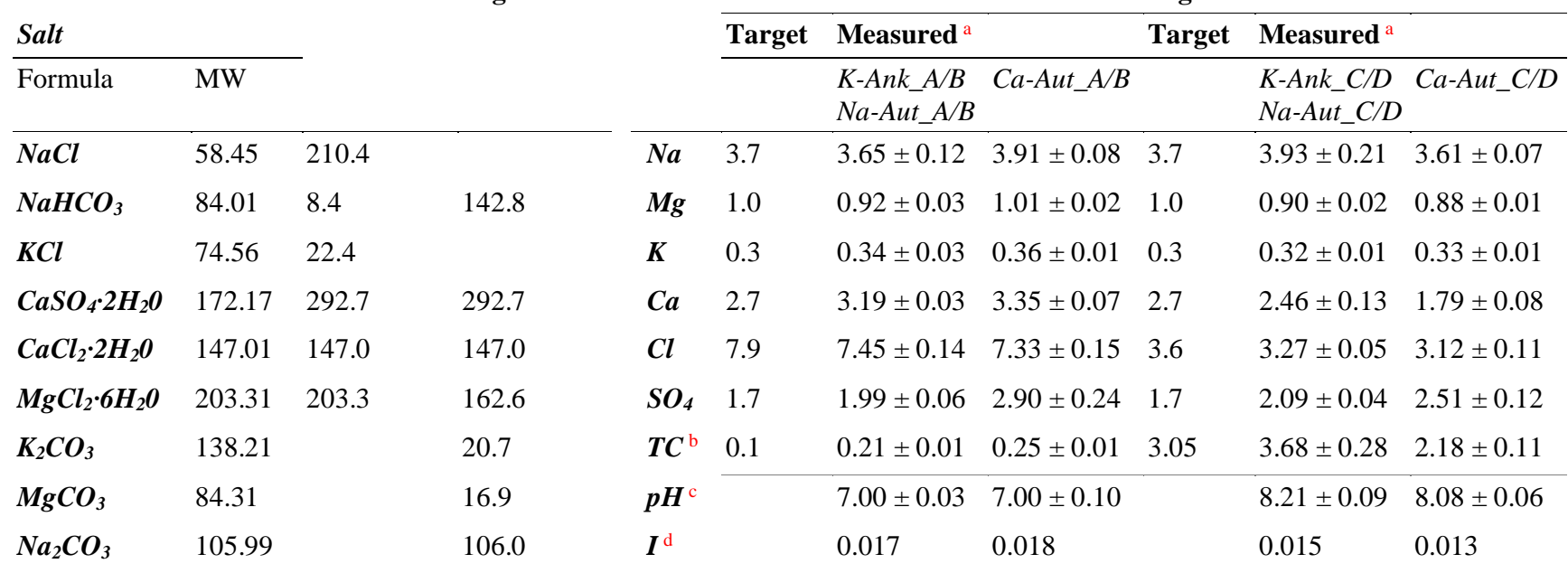

${ }^{\text {a }}$ Concentrations reported as average \pm 1 standard deviation of subsamples $(n=3-5)$ taken from input solution reservoirs over the course of the experiment. Individual measurements are shown in Figure S2. Reproducibility of measurements was $\leq$ $2 \% \mathrm{RSD}$ for $\mathrm{Na}, \mathrm{Mg}, \mathrm{K}$, and $\mathrm{Ca}$ concentrations, and $\leq 3 \% \mathrm{RSD}$ for $\mathrm{Cl}, \mathrm{SO}_{4}$, and $\mathrm{TC}$ concentrations.

${ }^{\mathrm{b}} \mathrm{TC}$ corresponds to dissolved total carbon.

${ }^{c}$ Solution $\mathrm{pH} \pm 1$ standard deviation $(\mathrm{n}=3-5)$ after transport through tubing ${ }^{4}$.

${ }^{\mathrm{d}}$ I corresponds to the influent solution ionic strength in $\mathrm{mol} \mathrm{L}^{-1}$. 


\section{S2.2 Experimental Transport and Physical Properties}

Table S2. Experimental conditions for K-ankoleite, Na- and Ca-autunite dissolution flow-through columns reacted with low and high carbonate background porewater (BPW) as influent solutions.

\begin{tabular}{|c|c|c|c|c|c|c|c|c|c|c|c|c|c|c|c|c|c|c|}
\hline \multirow[t]{3}{*}{ Column conditions } & \multirow[t]{3}{*}{$\begin{array}{l}\text { Column } \\
\text { Label }\end{array}$} & \multicolumn{2}{|c|}{$\begin{array}{l}\text { Experiment } \\
\text { duration }\end{array}$} & \multicolumn{2}{|c|}{ Mass in column } & \multirow{2}{*}{$\begin{array}{l}\text { Fluid } \\
\text { volume } \\
(V)^{\text {a }}\end{array}$} & \multicolumn{2}{|c|}{$\begin{array}{l}\text { Volume fraction } \\
\left(\phi_{\mathrm{m}}\right)^{\mathrm{b}}\end{array}$} & \multirow[t]{3}{*}{$\begin{array}{l}\text { Porosity } \\
(\phi)^{\mathrm{b}}\end{array}$} & \multirow{3}{*}{ 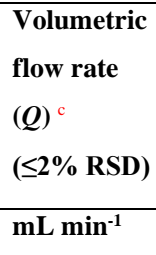 } & \multirow{3}{*}{$\begin{array}{l}\text { Linear fluid } \\
\text { velocity } \\
(v)^{\mathrm{d}} \\
( \pm 0.009) \\
\text { cm min }^{-1}\end{array}$} & \multirow{3}{*}{$\begin{array}{l}\text { Dispersion } \\
\text { coefficient } \\
\left(D_{L}\right)^{d} \\
( \pm 0.0007) \\
\text { cm }^{2} \text { min }^{-1}\end{array}$} & \multirow{3}{*}{$\begin{array}{l}\text { Dispersivity } \\
\left(\alpha_{\mathrm{L}}\right)^{\mathrm{e}} \\
( \pm \mathbf{0 . 0 1 1}) \\
\mathbf{c m}\end{array}$} & \multirow[t]{3}{*}{$\begin{array}{l}\text { Peclet } \\
\text { number }^{\mathrm{e}}\end{array}$} & \multicolumn{4}{|l|}{$\mathbf{U}_{\text {total }}$} \\
\hline & & & & Mixture & U-mineral & & Quartz & U-mineral & & & & & & & \multirow{2}{*}{$\begin{array}{l}\text { Initial }^{\mathrm{f}} \\
\text { mol }\end{array}$} & \multirow{2}{*}{$\begin{array}{l}\text { Dissolved }^{\mathrm{g}} \\
\text { mol }\end{array}$} & \multicolumn{2}{|c|}{ Remaining $^{\mathrm{h}}$} \\
\hline & & $\mathbf{h}$ & PV & g & g & $\mathbf{m L}$ & & & & & & & & & & & mol & $\%$ \\
\hline \multirow{2}{*}{$\begin{array}{l}\text { K-ankoleite + quartz } \\
+ \text { low } \mathrm{CO}_{3} \mathrm{BPW}\end{array}$} & K-Ank_A & 266 & 2050 & 1.8670 & 0.0525 & 0.3058 & 0.6811 & 0.0148 & 0.3041 & 0.038 & 0.059 & 0.0019 & 0.031 & 67 & $1.15 \cdot 10^{-4}$ & $8.93 \cdot 10^{-7}$ & $1.14 \cdot 10^{-4}$ & 99.2 \\
\hline & K-Ank_B & 266 & 1845 & 1.8541 & 0.0521 & 0.3106 & 0.6764 & 0.0146 & 0.3090 & 0.035 & 0.066 & 0.0034 & 0.051 & 41 & $1.14 \cdot 10^{-4}$ & $9.44 \cdot 10^{-7}$ & $1.13 \cdot 10^{-4}$ & 99.2 \\
\hline & Na-Aut_B & 266 & 1811 & 1.8507 & 0.0426 & 0.3112 & 0.6787 & 0.0117 & 0.3096 & 0.034 & 0.063 & 0.0025 & 0.040 & 51 & $9.63 \cdot 10^{-5}$ & $6.06 \cdot 10^{-6}$ & $9.03 \cdot 10^{-5}$ & 93.7 \\
\hline \multirow{2}{*}{$\begin{array}{l}\text { Ca-autunite + quartz } \\
+ \text { low } \mathrm{CO}_{3} \mathrm{BPW}\end{array}$} & Ca-Aut_A & 220 & 1887 & 1.8622 & 0.0362 & 0.3053 & 0.6854 & 0.0109 & 0.3037 & 0.043 & 0.058 & 0.0014 & 0.023 & 87 & $7.89 \cdot 10^{-5}$ & $4.52 \cdot 10^{-7}$ & $7.85 \cdot 10^{-5}$ & 99.4 \\
\hline & Ca-Aut_B & 220 & 1950 & 1.8751 & 0.0365 & 0.3005 & 0.6901 & 0.0110 & 0.2989 & 0.044 & 0.058 & 0.0013 & 0.022 & 93 & $7.95 \cdot 10^{-5}$ & $4.58 \cdot 10^{-7}$ & $7.90 \cdot 10^{-5}$ & 99.4 \\
\hline \multirow{2}{*}{$\begin{array}{l}\text { K-ankoleite + quartz } \\
+ \text { high } \mathrm{CO}_{3} \mathrm{BPW}\end{array}$} & K-Ank_C & 257 & 1715 & 1.8557 & 0.0521 & 0.3100 & 0.6770 & 0.0146 & 0.3084 & 0.034 & 0.043 & 0.0017 & 0.038 & 32 & $1.14 \cdot 10^{-4}$ & $1.89 \cdot 10^{-5}$ & $9.49 \cdot 10^{-5}$ & 83.4 \\
\hline & K-Ank_D & 257 & 1888 & 1.8744 & 0.0527 & 0.3030 & 0.6838 & 0.0148 & 0.3014 & 0.036 & 0.051 & 0.0020 & 0.038 & 56 & $1.15 \cdot 10^{-4}$ & $1.99 \cdot 10^{-5}$ & $9.51 \cdot 10^{-5}$ & 82.7 \\
\hline & Na-Aut_D & 257 & 1840 & 1.8435 & 0.0424 & 0.3139 & 0.6761 & 0.0117 & 0.3123 & 0.037 & 0.048 & 0.0016 & 0.033 & 62 & $9.60 \cdot 10^{-5}$ & $2.39 \cdot 10^{-5}$ & $7.21 \cdot 10^{-5}$ & 75.1 \\
\hline \multirow{2}{*}{$\begin{array}{l}\text { Ca-autunite + quartz } \\
+ \text { high } \mathrm{CO}_{3} \mathrm{BPW}\end{array}$} & Ca-Aut_C & 220 & 1355 & 1.8713 & 0.0364 & 0.3019 & 0.6888 & 0.0109 & 0.3003 & 0.031 & 0.038 & 0.0008 & 0.020 & 104 & $7.93 \cdot 10^{-5}$ & $7.51 \cdot 10^{-6}$ & $7.18 \cdot 10^{-5}$ & 90.5 \\
\hline & Ca-Aut_D & 220 & 1981 & 1.8861 & 0.0367 & 0.2963 & 0.6942 & 0.0110 & 0.2948 & 0.044 & 0.056 & 0.0014 & 0.025 & 80 & $7.99 \cdot 10^{-5}$ & $1.04 \cdot 10^{-5}$ & $6.96 \cdot 10^{-5}$ & 87.1 \\
\hline
\end{tabular}

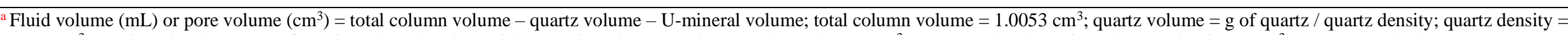
$2.65 \mathrm{~g} / \mathrm{cm}^{3} ; \mathrm{U}$-mineral volume $=(\mathrm{g}$ of U-mineral $/$ molecular weight $) \cdot \mathrm{U}$-mineral molar volume; molar volumes $\left(\mathrm{cm}^{3} / \mathrm{mol}\right)=$ molecular weight $/ \mathrm{density} ;$ density $\left(\mathrm{g} / \mathrm{cm}^{3}\right)=3.54(\mathrm{~K}$-ankoleite $), 3.62(\mathrm{Na}-$ autunite) and 3.31 (Ca-autunite) (from http://www.mindat.org/).

${ }^{\mathrm{b}}$ Volume fraction $=$ solid phase volume / total column volume; porosity = pore volume / total column volume .

${ }^{c}$ Determined by weight of effluent column samples.

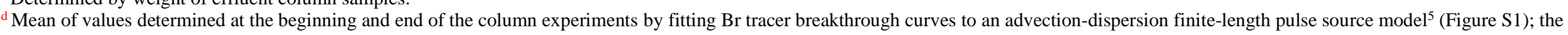
uncertainty is given as 1 standard deviation of all column experiments.

${ }^{\mathrm{e}}$ Dispersivity $\alpha_{\mathrm{L}}=D_{\mathrm{L}} / v$ (uncertainty as 1 standard deviation of all column experiments); peclet number $=\left(v \cdot \mathrm{L} / D_{\mathrm{L}}\right)$ with $\mathrm{L}($ column length $)=2 \mathrm{~cm}$.

${ }^{\mathrm{f}}$ Calculated from U-mineral quartz mixture preparation.

${ }^{g}$ Calculated by integrating the area of the released $U$ curve for each column system over the whole experiment duration.

${ }^{\mathrm{h}}$ In mol and as \% of the initial $\mathrm{U}_{\text {total. }}$. 

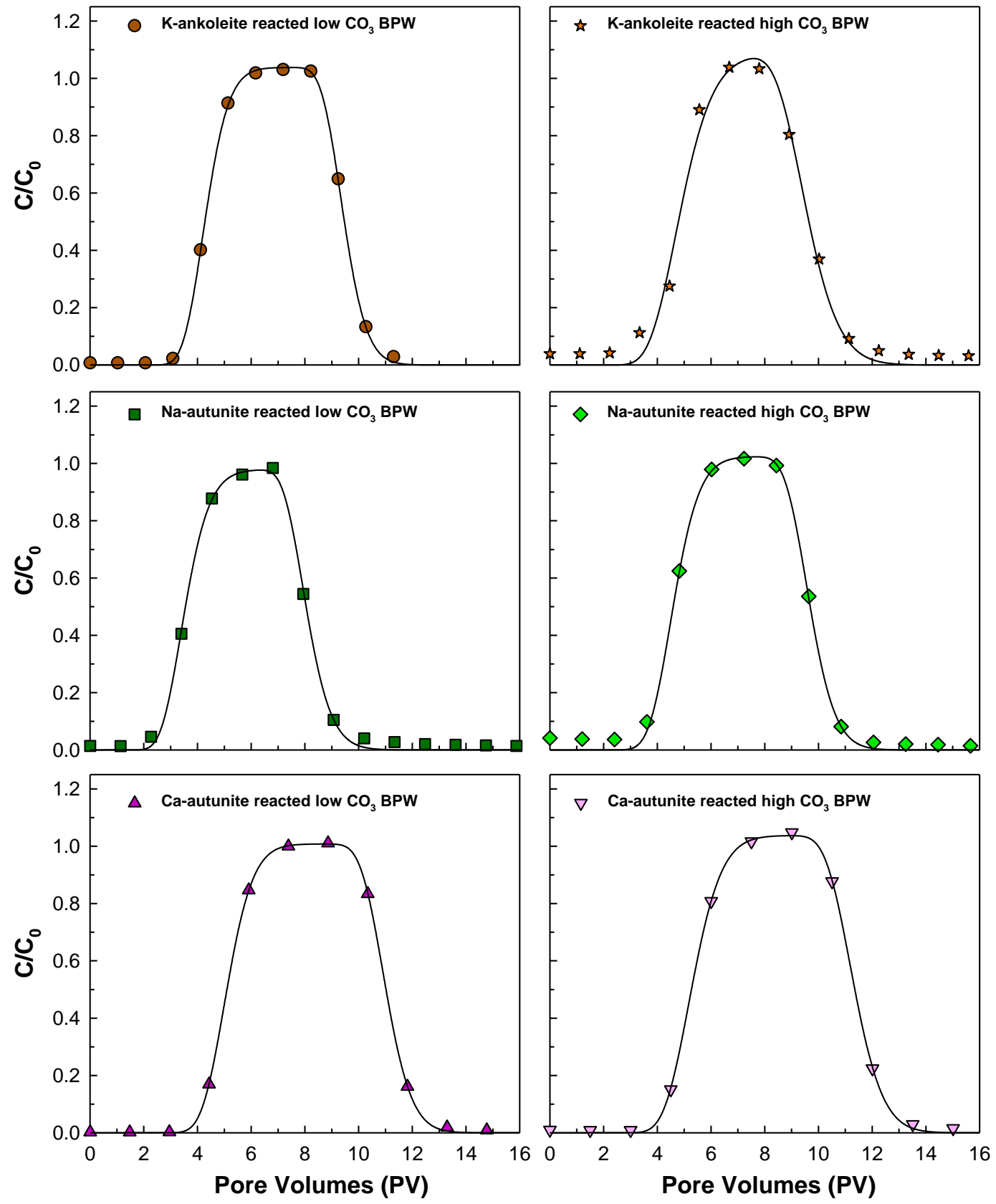

Figure S1. Representative $\mathrm{Br}$ conservative tracer breakthrough curves for flow-through columns of K-ankoleite (top), Na-autunite (middle), and Ca-autunite (bottom) columns reacted with low (left) and high (right) carbonate background porewater (BPW). A Br pulse $(0.1-0.3 \mathrm{mM} \mathrm{Br})$ of 40 or $42 \mathrm{~min}$ was used and data points were collected every $10 \min (1.2-1.5 \mathrm{PV})$. Solid lines represent the model curves obtained after optimizing linear fluid velocity $\left(v, \mathrm{~cm} \mathrm{~min}^{-1}\right)$ and dispersion coefficient $\left(D_{\mathrm{L}}, \mathrm{cm}^{2}\right.$ $\min ^{-1}$ ) using an advection-dispersion finite-length pulse source model ${ }^{5}$. Numerical values are reported in Table S2. 


\section{S3. Effluent Solutions Analyses}

\section{S3.1 Analytical Methodology}

$p H$

The $\mathrm{pH}$ was measured off-line with a daily-calibrated $\mathrm{pHmeter}$ and an Accumet combination pH micro-electrode (Cole Parmer) in 14-19 individual effluent samples per column experiment.

\section{Inductively coupled plasma-mass spectrometry (ICP-MS)}

Uranium, $\mathrm{P}, \mathrm{Na}, \mathrm{Ca}, \mathrm{K}, \mathrm{Mg}$ and $\mathrm{Br}$ concentrations from effluent solutions $(<0.45 \mu \mathrm{m})$ and acid digests were measured using ICP-MS (Agilent 7500ce Cetac - ASX-510 Autosampler). Samples and standards were analyzed in $2 \% \mathrm{HNO}_{3}$ matrix and the latter were freshly prepared from $1000 \mu \mathrm{g} \mathrm{mL}^{-1}$ ICP standard solutions obtained from GFS Chemicals, Inorganic Ventures and Fluka Chemicals. Blank and check standard solutions were analyzed every 1012 samples to account for any signal drift. The detection limits of the method were 13-25 ng $\mathrm{L}^{-1}\left(\leq 1.1 \cdot 10^{-10} \mathrm{M}\right)$ for $\mathrm{U}, 0.7-3.1 \mu \mathrm{g} \mathrm{L} \mathrm{L}^{-1}\left(\leq 1.0 \cdot 10^{-7} \mathrm{M}\right)$ for $\mathrm{P}$, and between $0.1-3.5 \mu \mathrm{g} \mathrm{L}^{-1}(\leq$ $8.7 \cdot 10^{-8} \mathrm{M}$ ) for $\mathrm{Na}, \mathrm{Mg}, \mathrm{K}, \mathrm{Ca}$, and $\mathrm{Br}$. The repeatability of the analyses, as relative standard deviation (RSD), was always $\leq 2 \%$ for all elements.

Ion chromatography (IC) and total dissolved carbon (TC)

The concentration of anions $\left(\mathrm{Cl}^{-}, \mathrm{SO}_{4}{ }^{2-}\right)$ in effluent solutions (diluted with ultrapure water) was determined using a Dionex ICS-2000 chromatography system (AS18 chromatographic column) with suppressed conductivity detection. The TC concentration was analyzed in undiluted effluent solutions using a Shimadzu TOC-Vcsh Total Organic Carbon Analyzer coupled with an ASI 5000A autosampler.

IC and TOC systems were daily calibrated with standard solutions freshly prepared from a seven anion IC aqueous standard (1000 $\mu \mathrm{g} \mathrm{mL}^{-1}$; Dionex) and a potassium hydrogen phthalate $\left(\mathrm{C}_{6} \mathrm{H}_{4}(\mathrm{COOK})(\mathrm{COOH})\right)$ stock solution $\left(1000 \mu \mathrm{g} \mathrm{mL} \mathrm{mL}^{-1}\right)$, respectively. Standard checks and blanks were run every 10-15 samples to account for signal drift. The limit of detection was $10-25 \mu \mathrm{g} \mathrm{L}-1\left(0.1-0.7 \cdot 10^{-6} \mathrm{M}\right)$ for both anions and $50 \mu \mathrm{g} \mathrm{L} \mathrm{L}^{-1}\left(4.2 \cdot 10^{-6} \mathrm{M}\right)$ for dissolved TC. Both analytical techniques presented a measurement RSD of $<3 \%$. 


\section{S3.2 Effluent Solutions Results}

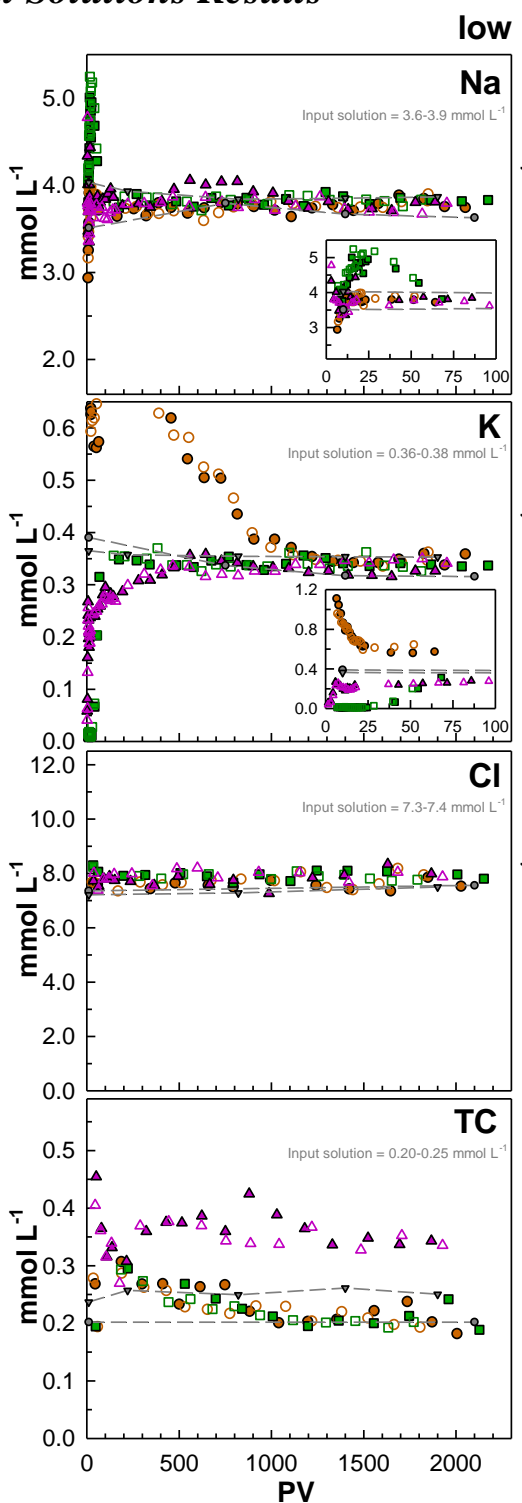

low $\mathrm{CO}_{3} \mathrm{BPW}$

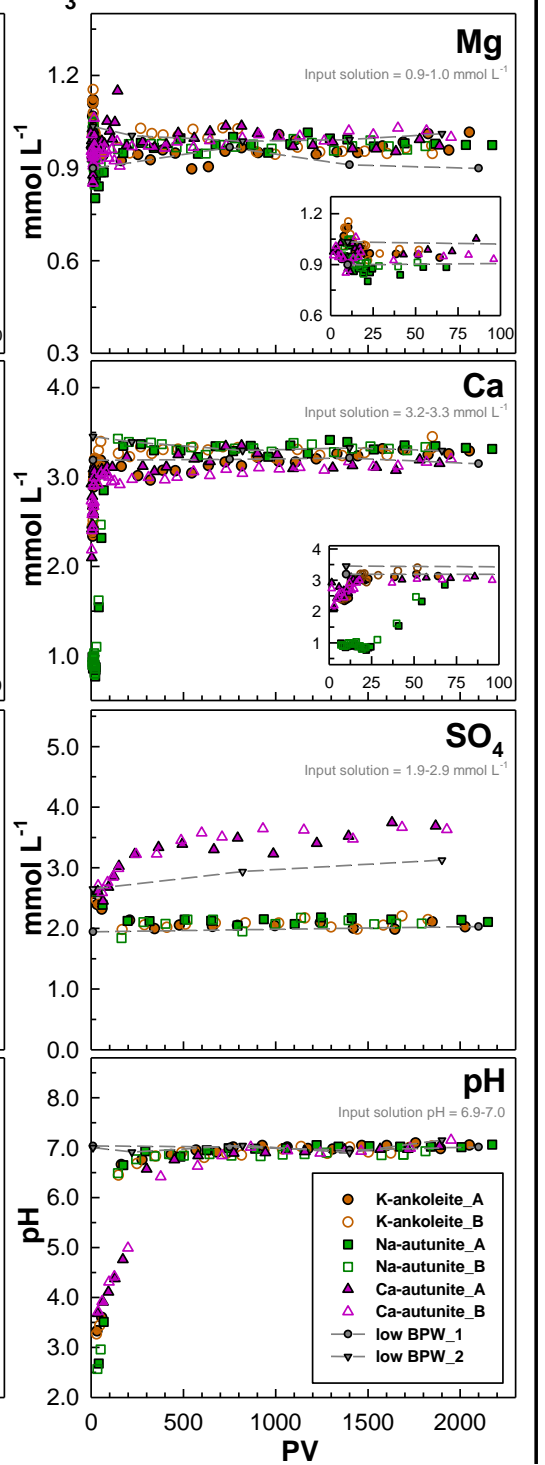

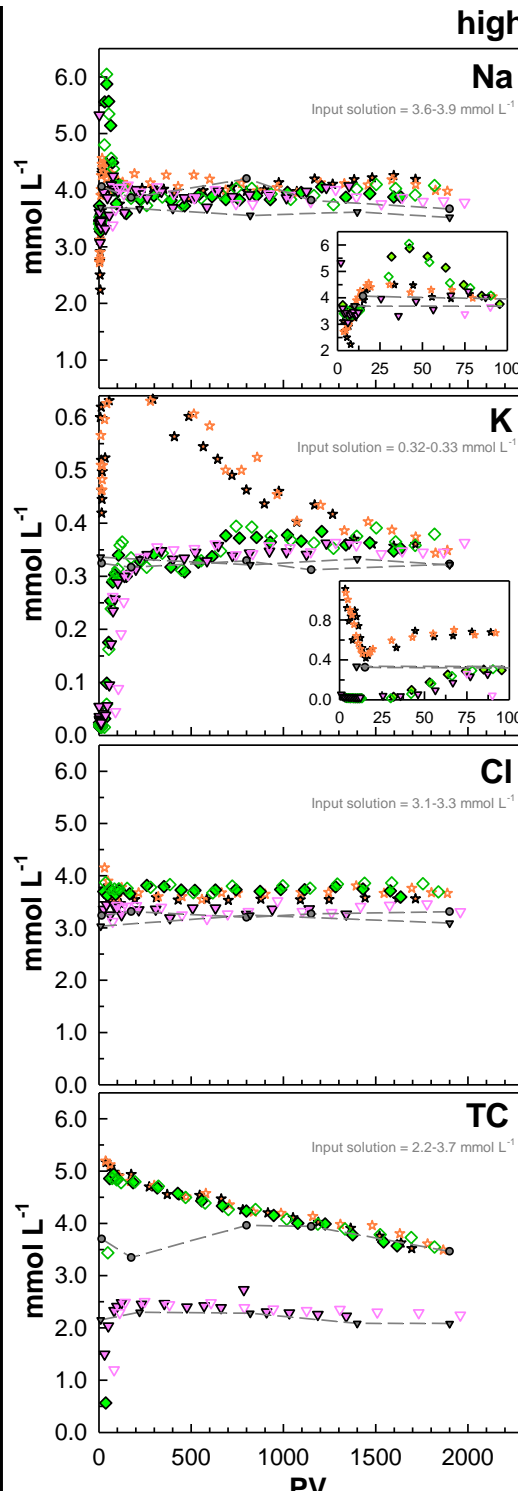

high $\mathrm{CO}_{3} \mathrm{BPW}$

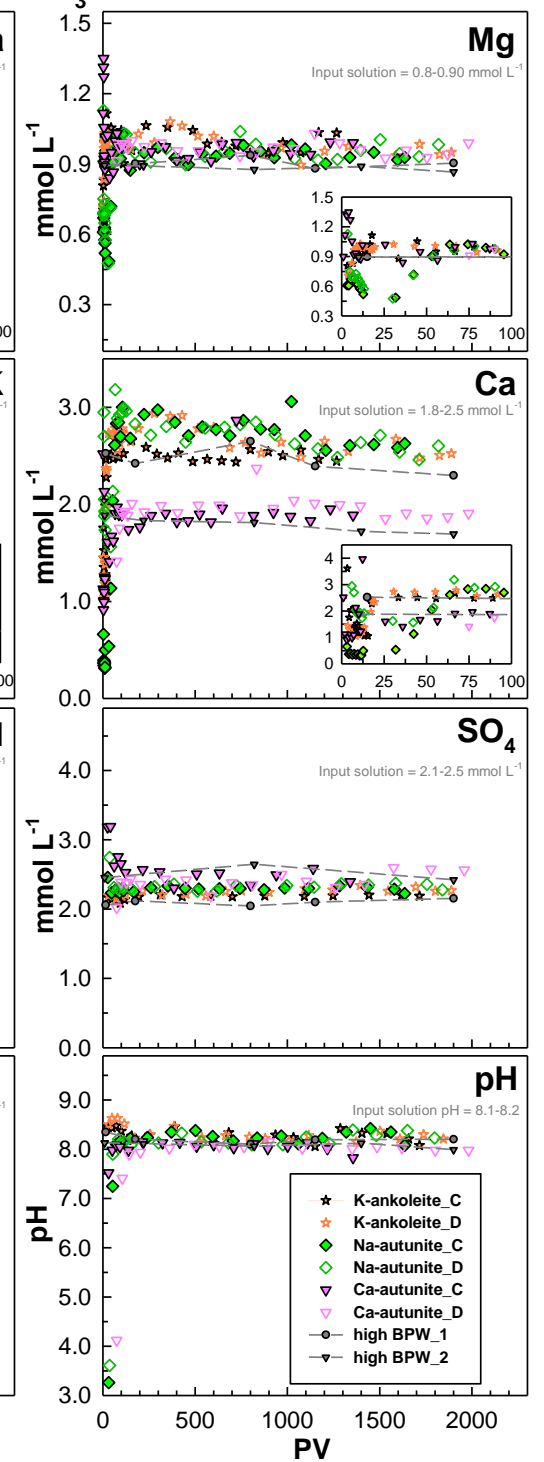

Figure S2. Concentration of effluent $\mathrm{Na}, \mathrm{Mg}, \mathrm{K}, \mathrm{Ca}, \mathrm{Cl}^{-}, \mathrm{SO}_{4}{ }^{2-}$, dissolved total carbon (TC) and $\mathrm{pH}$ measured over time (in pore volumes, $\mathrm{PV}$ ) for duplicate $\mathrm{K}$ ankoleite (circles/stars), Na-autunite (squares/diamonds), and Ca-autunite (triangles/inverted triangles) flow-through columns reacted with low (left) and high (right) carbonate background porewater (BPW). Circle/triangle-dashed lines are measured concentrations in BPW input solutions. Plot insets show data for the first 100 PV (i.e., from 0 to $11-16 \mathrm{~h}$ ) and have the same concentration units as the main plots. 


\section{S4. Solid Phase Characterization}

\section{S4.1 Analytical and Spectroscopy Methodology}

\section{Surface Area}

Specific surface area (SSA) was determined on dried samples by the $\mathrm{N}_{2}$-BET method (Brunauer-Emmett-Teller (BET)) using a surface area analyzer (Tri-Star 3000, Micrometrics).

Thermogravimetric Analyses (TGA)

The water content of the uranyl minerals was determined by TGA by heating $~ 20 \mathrm{mg}$ of airdried mineral powder from room temperature to $600^{\circ} \mathrm{C}$ at $10^{\circ} \mathrm{C} \mathrm{min}^{-1}$ in an Ar purge (2000 $\mathrm{mL} \mathrm{min}^{-1}$ ) using a Seiko model TGA/DTA 320. Number of water molecules (hydration and structural water) was calculated from the weight loss at the temperature range $20-400^{\circ} \mathrm{C}$.

Elemental Analysis of Solids

Microwave acid digestion (40 min, $160^{\circ} \mathrm{C}, 18$ bar; Anton Paar Multiwave 3000) was carried out in duplicate by adding $9 \mathrm{~mL} \mathrm{HCl}$ and $3 \mathrm{~mL} \mathrm{HNO}_{3}$ to $0.04-0.06 \mathrm{~g}$ of air-dried samples. The digests were subsequently diluted with ultrapure water to a final $1-5 \% \mathrm{HNO}_{3} \mathrm{v} / \mathrm{v}$ concentration for ICP-MS analysis.

Vibrational Spectroscopy (Raman and Fourier Transform Infrared (FTIR))

An ExamineR 785 (DeltaNu, Laramie, WY) Raman module equipped with a 785 nm, 120 $\mathrm{mW}$ laser excitation source, a CCD detector $\left(0.5 \mathrm{~cm}^{-1}\right.$ resolution $)$ and an Olympus BX51 microscope (50x objective, 0.75 numerical aperture) was used to collect the Raman spectra on single crystals (30 s integration time), and to confirm uranyl bonds and hydration of the minerals. No corrections were performed on the measured spectra. FTIR reflectance spectra (25 per sample) were acquired on a Bruker, Alpha-P infrared reflectance spectrometer. Solid samples were directly loaded in the diamond window. Spectra were averaged for each sample using the OPUS/Mentor Operating software.

SEM Imaging and Particle Size

Air-dried particles of the minerals (no conductive coating) stuck on carbon conductive tabs were imaged using a FEI Quanta 200 environmental scanning electron microscope (ESEM) with a tungsten filament. Secondary-electron (SE) images were obtained at high vacuum (< $10^{-4}$ Torr), $20 \mathrm{kV}$ voltage and 90-100 $\mu \mathrm{A}$ emission current. When imaging column mixture 
materials, U-mineral particles were identified among quartz particles by the shape and intensity of charged surface. Quartz particles were big, blocky and sharped-edgy with heavily charged-surface, whereas U-mineral particles exhibited a non-charged surface with softer, curved edges, and the platelets formation was clearly visible. As qualitative evaluation, the size of uranyl phosphate particles observed on the SEM images of unreacted $(n=14-72)$ minerals and reacted with low $(n=22-94)$ and high $(n=36-77)$ carbonate BPW was estimated using the measuring tool of ImageJ $1.51 \mathrm{k}$ software ${ }^{6}$. Estimated particle sizes of each mineral were classified in small $(<50 \mu \mathrm{m})$, intermediate $(50-250 \mu \mathrm{m})$, and large $(>$ $250 \mu \mathrm{m})$ to find the median of each size range.

\section{$X$-ray Diffraction $(X R D)$}

Laboratory analysis (lab-XRD): freshly synthesized chernikovite, K-ankoleite, Na-autunite and Ca-autunite minerals were mounted on zero-background Si holders and scanned from 4 to 80 degrees $2 \theta$ (0.01 steps) using a Philips X'Pert MPD diffractometer equipped with an ultra-fast $X^{\prime}$ Celerator detector (Ni-filtered Co-K $\alpha$ radiation source, $\lambda=1.7890 \AA$ ) operated at $50 \mathrm{kV}$ and $40 \mathrm{~mA}$.

Synchrotron analysis (syn-XRD): X-ray diffractograms of unreacted and reacted K-ankoleite, $\mathrm{Na}$-autunite and $\mathrm{Ca}$-autunite, and unreacted quartz were collected after column experiments at the Stanford Synchrotron Radiation Lightsource (SSRL) on beam line 11-3 operating at $\sim 12.7 \mathrm{keV}(\lambda=0.9765 \AA)$ in transmission mode, using a $345 \mathrm{~mm}$ radius Mar detector with $100 \mu \mathrm{m}$ pixels. A small amount of mineral $(\sim 10-15 \mathrm{mg}$; for reacted column mixtures, mineral particles were manually separated from quartz particles after air drying) was ground and packed between two layers of Kapton tape to obtain a homogeneous thin layer sample. After calibration of the detector using finely ground LaB6 crystals, three scans were collected per sample. Data were reduced using the Area Diffraction Machine Software ${ }^{7}$ with a mask covering the beamstop, patterns of replicates were added and their background determined. Both sets of diffractograms, lab- and syn-XRD, were treated for background and converted to $\mathrm{Cu}-\mathrm{K} \alpha$ radiation wavelength for ease of comparison across XRD data. X'Pert HighScore Plus software was used for peak identification and quantitative phase analysis (Rietveld software module) using a combination of the International Center for Diffraction Data (ICDD) reference spectra library ${ }^{8}$, references from the American Mineralogist Crystal Structure database (AMCSD) ${ }^{9}$ and the Crystallography Open Database (COD) ${ }^{10,11}$, and crystal structures extracted from the literature. Diffractograms were modeled for scale factor, 
preferred orientation and peak shape (including March-Dollase factor) following the method described in Perdrial, et al. ${ }^{12}$. As per HighScore Plus manual, this approach is accurate for phases $>0.5 \%$ by mass.

\section{$X$-ray Absorption Spectroscopy (XAS)}

Uranium L LII-edge Extended X-ray absorption fine structure (EXAFS) spectra were collected on beamlines 4-1 and 11-2 at the Stanford Synchrotron Radiation Lightsource (current 500 $\mathrm{mA})$. Unreacted synthesized K-ankoleite, Na-autunite and Ca-autunite minerals ( 15-20 mg) were diluted with sucrose (1:4 ratio) to achieve a maximum log absorbance $\left(\mathrm{I}_{0} / \mathrm{I}_{\mathrm{t}}\right) \sim 1$ in transmission mode. For reacted minerals, $\sim 20-200 \mathrm{mg}$ of column mixtures (calculated based on effluent measurements) were ground manually and diluted with sucrose to $2000 \mathrm{ppm} \mathrm{U}$ for fluorescence mode. Samples were loaded in Al holders, sealed with Kapton tape and held in a liquid nitrogen cryostat to maintain low vacuum and temperature ( $77 \mathrm{~K})$. Samples were measured using a $\mathrm{Si}(220)$ monochromator crystal with the second crystal detuned $20-30 \%$ at $17,600 \mathrm{eV}$ to reject harmonic reflections. Beam size on the sample was 1 x 4-7 mm and XAS data was collected with either a 30- or 100-element solid-state Ge fluorescence detector.

Three and four scans per sample were collected in transmission and fluorescence mode, respectively. Scans were averaged using SIXpack ${ }^{13}$, and background subtraction, normalization, and EXAFS fits were performed with the ATHENA and ARTEMIS software package ${ }^{14}$. Background was subtracted by a linear fit through the pre-edge region and a spline fit through the EXAFS region $\left(\mathrm{k}=0 \AA^{-1}\right.$ was set to $\left.17,185 \mathrm{eV}\right)$ using Autoback in ATHENA. Spectra were normalized to the post-edge step height.

Non-linear least-squares shell-by-shell EXAFS fits $\left(\mathrm{k}^{3}\right.$-weighing; $\mathrm{k}$-range $=2-14.6 \AA^{-1}$; Rrange $=1.1-6 \AA$ ) were carried out using ARTEMIS on the unreacted minerals to verify the local bonding environment of U(VI) compared to published crystal structure analysis ${ }^{15-18}$; the reported interatomic distances therein were used as the initial model for the calculation of the theoretical EXAFS spectra. Groups of backscattering atoms at similar interatomic distances were determined by trial-and-error fitting based on this ideal crystal structure. The amplitude reduction factor $\left(\mathrm{S}_{0}^{2}\right)$ was set to 1 and energy shift $\left(\Delta \mathrm{E}_{0}\right)$ was linked as a single parameter for all shells. For uranyl bonded to 2 axial oxygen atoms ( $\left.U-\mathrm{O}_{\mathrm{ax}}\right)$, coordination number $(\mathrm{N})$ was fixed at 2 for single scattering (SS) and 2 for multiple scattering (MS), distance (R) was constrained to double the SS distance, and Debye-Waller factors $\left(\sigma^{2}\right)$ were allowed to vary. 
For all other shells, $\mathrm{N}$ was fixed on the weighted average of all $\mathrm{U}$ environments in the crystal structure for a given shell, and $\sigma^{2}$ and $\mathrm{R}$ varied.

The EXAFS spectra of reacted columns were analyzed by both least-squares linear combinations of uranyl reference compound spectra and shell-by-shell fits with theoretical standards to identify changes in the U(VI) bonding environment due to dissolution. Reference compounds included the four unreacted uranyl phosphates from this work, meta-ankoleite, phosphuranylite, schoepite and uranyl nitrate spectra from Kanematsu, et al. ${ }^{19}$, and Kcompreignacite, Na-compreignacite, becquerelite and uranyl sorbed on quartz from ReinosoMaset, et al. ${ }^{4}$. Component weights of the reference spectra were constrained between 0 and 1 in linear combination fits but not forced to sum to unity. Components with a fraction of less than $10 \%$ in the fit were discarded, as they did not significantly improve fit statistics. Spectra were also fit by shell-by-shell analysis as described above (k-weight $=3$; k-range $=2-14.6$ $\AA^{-1}$; R-range $=1.1-6 \AA$ ) except that $\sigma^{2}$ was fixed to the value or average value obtained in fits to unreacted minerals' spectra for a given backscattering atom, and $\mathrm{R}$ and $\mathrm{N}$ were allowed to vary.

\section{S4.2 Mineral Phase Characterization Results}

\section{S4.2.1 General Characteristics}

\section{Unreacted Minerals}

Synthesized K-ankoleite and Na-autunite minerals were mainly blocky particles (200-1000 $\mu \mathrm{m})$ surrounded by smaller particles $(5-50 \mu \mathrm{m})$, whereas Ca-autunite formed agglomerations (50-200 $\mu \mathrm{m})$ of plately particles and hairy filaments. Chernikovite displayed 5- to 8-sided particles (4-40 $\mu \mathrm{m}$ sides) formed by 3-4 $\mu \mathrm{m}$ thick platelets (Figures 2 and S3). Na-autunite and Ca-autunite minerals had similar $\mathrm{N}_{2}$-BET specific surface areas (2.0-2.1 $\left.\mathrm{m}^{2} \mathrm{~g}^{-1}\right)$ but one unit lower than K-ankoleite (Table S3). The latter contained the same water molecules (5.56.0) in the mineral structure as $\mathrm{Ca}$-autunite, which was one less than in Na-autunite and chernikovite minerals (Table S3). This difference was also observed in the FTIR and Raman spectra (Figure S4), where the wavelength bands of $\mathrm{OH}$ vibrations in water molecules were common for $\mathrm{K}$-autunite and $\mathrm{Ca}$-autunite but different from $\mathrm{Na}$-autunite and chernikovite bands. Common bands corresponding to $\mathrm{PO}_{4}$ and $\mathrm{UO}_{2}$ bending and stretching vibrations were observed in K-autunite, Na-autunite and chernikovite spectra, whereas most of these 
vibrational bands were of different shape and wavelength for Ca-autunite (Figure S4). See next section and Table S4 for details on band assignment.

Elemental analysis of unreacted minerals (Table S3) resulted in U:P ratios ranging within the expected stoichiometric ratio of 1 for these autunite-type minerals $(0.98-1.06 ; 1.21$ for chernikovite). However, the ratio of $U$ to the main interlayer cation present in each mineral structure differed from theoretical structures values (1.1 U:K, 5.3 U:Na, 2.7 U:Ca). Accounting for other cations and charge balance decreased the $\mathrm{U}$ :cation ratio for $\mathrm{K}$-ankoleite (1.0) and Na-autunite (3.3) due to the presence of Ca. However, no significant $\mathrm{Na}, \mathrm{Mg}$ or $\mathrm{K}$ concentrations were detected in Ca-autunite, thus increasing the ratio to 5.04. A small amount of $\mathrm{Na}$ and $\mathrm{K}$ was detected in unreacted chernikovite generating a $3.63 \mathrm{U}$ :cation ratio.

The quartz material used as the column filler was characterized before and after reaction with BPW input solutions for elemental composition and $\mathrm{N}_{2}$-BET by Reinoso-Maset, et al. ${ }^{4}$ (results reported in Table S3). In this work, SEM imaging (Figure S3) and syn-XRD (see section S4.2.2) were also carried out in unreacted quartz material. SEM images showed quartz particles of $200-400 \mu \mathrm{m}$ in size (as expected from provider's specifications).

\section{FTIR and Raman Spectra and Band Assignment}

FTIR and Raman spectra of unreacted minerals presented common vibrational bands but with some differences in wave number (Figure S4, Table S4). In the FTIR spectra, bending and stretching bands of $\mathrm{PO}_{4}$ and $\mathrm{UO}_{2}$ groups within the mineral structure were observed between 400 and $1200 \mathrm{~cm}^{-1}$. The K-ankoleite, Na-autunite and chernikovite spectra presented a strong band at $542-543 \mathrm{~cm}^{-1}$ corresponding to the $\mathrm{PO}_{4}$ antisymmetric bending vibration, whereas this band was at slightly shorter wavelength for $\mathrm{Ca}$-autunite. The symmetric stretching for $\mathrm{UO}_{2}$ groups was only present as weak bands between 816 and $825 \mathrm{~cm}^{-1}$ in the K-ankoleite (double band), Na-autunite and chernikovite spectra. The corresponding antisymmetric stretching vibration for $\mathrm{UO}_{2}$ was shown as a strong band of shorter wavenumber for $\mathrm{K}$ ankoleite than for the other minerals (908 vs. $\left.915-919 \mathrm{~cm}^{-1}\right)$. The symmetric stretching vibration band of $\mathrm{PO}_{4}$ groups was the strongest peak observed for all minerals, at $\sim 990 \mathrm{~cm}^{-1}$ for K-ankoleite and Na-autunite and at $975 \mathrm{~cm}^{-1}$ for chernikovite. In Ca-autunite, this vibration band was reduced in intensity and composed by two bands at 965 and $994 \mathrm{~cm}^{-1}$. The corresponding antisymmetric vibration was presented as weak shoulders at 1091-1094 $\mathrm{cm}^{-1}$, except for K-ankoleite which was at $1110 \mathrm{~cm}^{-1}$. The vibration bands for $\mathrm{OH}$ bending and stretching in water molecules were weak and broad in the four minerals. The main difference 
is found in the $\mathrm{OH}$ bending bands located between 1600 and $2000 \mathrm{~cm}^{-1}$. K-ankoleite and Caautunite presented a sharper peak at $\sim 1620 \mathrm{~cm}^{-1}$, which correspond to $\mathrm{H}_{2} \mathrm{O}$ molecules, while Na-autunite and chernikovite had a broader band at $\sim 1715 \mathrm{~cm}^{-1}$. The vibration corresponding to the $\mathrm{O}-\mathrm{H}$ bound stretching was identified in the $3000-3400 \mathrm{~cm}^{-1}$ region, with slight changes in wavenumber between minerals.

In the Raman spectra, the antisymmetric stretching of $\mathrm{UO}_{2}$ and $\mathrm{PO}_{4}$ groups was observed for all minerals as very weak bands at 290 and $400 \mathrm{~cm}^{-1}$, respectively. The strongest band corresponded to the symmetric stretching vibration of $\mathrm{UO}_{2}$ groups at $820-845 \mathrm{~cm}^{-1}$, with Kankoleite band at shorter wavenumber than the Na-autunite and chernikovite bands. Caautunite Raman spectrum presented a multiple peak for this vibrational band, resulting in lower intensity. Similar differences were observed for the symmetric stretching of $\mathrm{PO}_{4}$ groups at $990-1000 \mathrm{~cm}^{-1}$, as the Ca-autunite band was split into a lower and higher band, with the band at $1009 \mathrm{~cm}^{-1}$ corresponding to the antisymmetric stretching. Chernikovite band was slightly broader due to a shoulder peak at $986 \mathrm{~cm}^{-1}$. For all minerals, the $\mathrm{OH}$ stretching bands of water molecules were observed as very weak bands at ca. 3030 and $3360 \mathrm{~cm}^{-1}$.

\section{Minerals After Reaction}

After reaction with low carbonate BPW solutions, no changes to $\mathrm{K}$-ankoleite particle surfaces were observed, while Na-autunite had a rougher and more fractured surface (Figures 2 and S3). The median size estimated from SEM images of the largest particles was not significantly altered (675 and $715 \mu \mathrm{m}$ for K-ankoleite and Na-autunite, respectively), but small $(<45 \mu \mathrm{m})$ and intermediate particles $(75-330 \mu \mathrm{m})$ appeared following reaction. The size of Ca-autunite plately-particles agglomerates did not change significantly (60-210 $\mu \mathrm{m}$ range), but the particle surfaces had fewer hairy-filament type particles and new $<50 \mu \mathrm{m}$ particles were formed. Reaction with high carbonate BPW decreased the median size of the biggest K-ankoleite and Na-autunite particles (460-490 $\mu \mathrm{m})$, and for the three minerals, notably increased the surface roughness (Figures S3). Moreover, intermediate particles disappeared in favour of an increase of small particles, especially for Ca-autunite.

Independently of the carbonate content in the BPW solutions, the SSA of the three column mixtures decreased by $0.23-0.34 \mathrm{~m}^{-2} \mathrm{~g}^{-1}$, which corresponds to $56-68 \%$ reduction of SSA and approaches the SSA of the quartz columns (Table S3). Since the quartz particles undergo insignificant dissolution, SSA changes were due to changes of the U-mineral fraction within the column mixtures. The high initial U release in both BPW systems (Figure 1) suggests 
rapid dissolution and/or flush-out of fine mineral particles that likely contributed to a large fraction of the SSA measured in the initial mixture. Consequently, the removal of the finer particles resulted in column mixtures mostly composed of the larger U-mineral particles (as observed in the SEM images; Figure S3) with SSA closer to the quartz columns.

Nevertheless, these fine particles (as the U amount released in the first $75 \mathrm{PV}$ ) represented a small fraction of the initial total U mass, i.e., $0.5-1.7 \%$ for K-ankoleite $2.8-5.0 \%$ for $\mathrm{Na}-$ autunite, and 0.3-0.5 \% for Ca-autunite released in low and high carbonate BPW systems. The total cation concentrations in the solids also changed after reaction with either BPW solution (Table S3). The reacted K-ankoleite column mixtures showed 2.5-3 times lower K concentration, and $\mathrm{Na}$ concentration in Na-autunite columns were within measurement error, whereas $\mathrm{P}$ and $\mathrm{U}$ content in both mineral columns was 1.1-2.3 times higher. This resulted in 3.5 to 8 times higher $\mathrm{U}$ to $\mathrm{K}$ or Na molar ratio relative to 1.1-1.3 U:K and 4.4-5.3 U:Na for unreacted materials. However, due to a significant increase in Ca concentration from below detection limit to ca. 150 and $23 \mu \mathrm{mol} \mathrm{g}{ }^{-1}$, and a slight 1.9-2.7 fold increase in $\mathrm{Mg}$ concentration, the molar ratio of $U$ to all measured cations (accounting for charge balance) remained unchanged for K-ankoleite ( 1.1-1.7) and decreased for Na-autunite from ca. 3.55.0 to 0.6 and 2.5 in low and high carbonate BPW systems, respectively. In the case of Caautunite, reaction with both BPW solutions decreased three-fold the $\mathrm{U}$ and $\mathrm{P}$ content relative to the unreacted mineral, whereas Ca content was only two times lower; thus, the initial U:P ratio was unaffected (1.0-1.1 for the three unreacted minerals) and $\mathrm{U}: \mathrm{Ca}$ decreased slightly from 2.7-2.9 to 2.1-2.3. The U:cation ratio underwent a similar decrease (from ca. 4.0-5.0 to 2.5-3.4), as the other cations were at the same concentration range before and after reaction. 

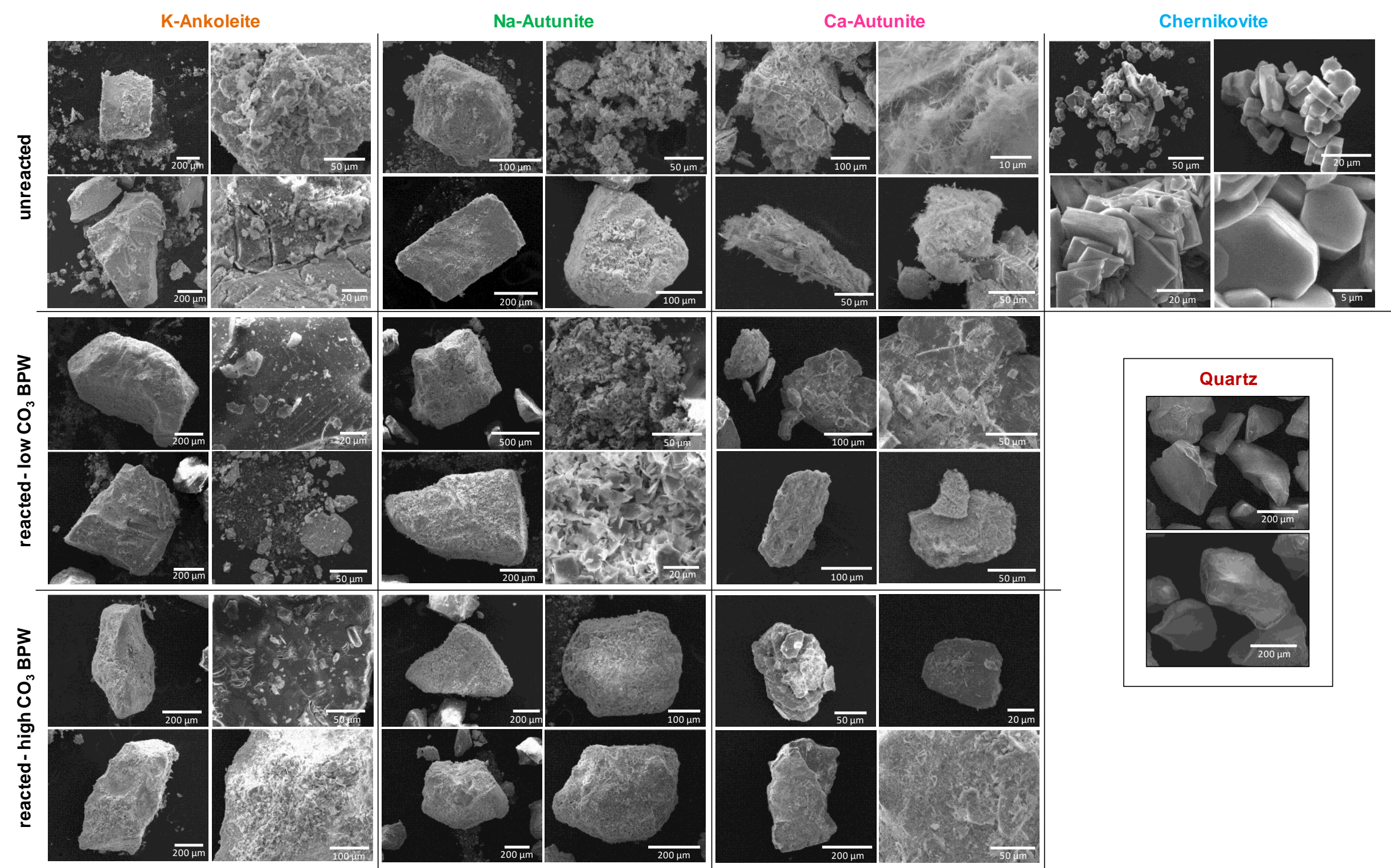

Figure S3. SEM images of synthetic K-ankoleite, Na-autunite, Ca-autunite, chernikovite and quartz minerals unreacted and reacted with low and high carbonate background porewater (BPW). 
Table S3. Characterization of K-ankoleite, Na-autunite, Ca-autunite and chernikovite synthetic minerals ("pure"), and uranyl phosphate mineral and quartz column mixtures before ("unreacted") and after reaction with low and high carbonate background porewater ("reacted low" and "reacted high"). Results for onlyquartz control column experiments were also included for comparison.

\begin{tabular}{|c|c|c|c|c|c|c|c|c|c|c|c|}
\hline \multirow{2}{*}{$\frac{\text { Mineral }}{\text { K-ankoleite }}$} & \multirow[t]{2}{*}{ Sample } & \multirow[t]{2}{*}{$\operatorname{SSA}\left(\mathbf{m}^{2} \mathbf{g}^{-1}\right)^{\mathrm{d}}$} & \multicolumn{6}{|c|}{ Element concentration $\left.(\mu \mathrm{mol} \mathrm{g})^{-1}\right)^{\mathrm{e}}$} & \multicolumn{3}{|c|}{ Element ratios $^{\mathrm{f}}$} \\
\hline & & & {$[\mathrm{Na}]$} & {$[\mathrm{Mg}]$} & {$[\mathbf{K}]$} & [Ca] & {$[\mathbf{P}]$} & [U] & $\mathrm{U}: \mathbf{P}$ & $\mathrm{U}: \mathrm{K}$ & U:cation ${ }^{g}$ \\
\hline $\mathrm{K}_{2}\left(\mathrm{UO}_{2}\right)_{2}\left(\mathrm{PO}_{4}\right)_{2} \cdot n \mathrm{H}_{2} \mathrm{O}$ & pure & $3.135 \pm 0.017$ & $63 \pm 12$ & $34 \pm 7$ & $2140 \pm 421$ & $276 \pm 54$ & $2461 \pm 497$ & $2421 \pm 624$ & $1.0 \pm 0.1$ & $1.1 \pm 0.1$ & $1.1 \pm 0.0$ \\
\hline $11.70 \%$ mass loss $(n=6.0)^{\mathrm{a}}$ & unreacted & $0.528 \pm 0.007$ & $1.1 \pm 1.6$ & $4.0 \pm 5.7$ & $22 \pm 2$ & $0.4 \pm 0.6$ & $26 \pm 4$ & $28 \pm 4$ & $1.2 \pm 0.3$ & $1.3 \pm 0.3$ & $1.2 \pm 0.5$ \\
\hline \multirow[t]{2}{*}{$\mathrm{MW}^{\mathrm{b}}=916.1$} & reacted low & $0.233 \pm 0.069$ & $1.6 \pm 3.2$ & $7.7 \pm 12.1$ & $9.1 \pm 4.1$ & $148 \pm 84$ & $30 \pm 3$ & $57 \pm 8$ & $1.9 \pm 0.3$ & $6.6 \pm 3.0$ & $1.0 \pm 0.8$ \\
\hline & reacted high & $0.186 \pm 0.019$ & $4.0 \pm 1.1$ & $0.5 \pm 0.1$ & $8.8 \pm 2.1$ & $23 \pm 4$ & $38 \pm 10$ & $42 \pm 11$ & $1.1 \pm 0.0$ & $4.7 \pm 0.5$ & $1.7 \pm 0.3$ \\
\hline Na-autunite & & & {$[\mathrm{Na}]$} & {$[\mathrm{Mg}]$} & {$[\mathbf{K}]$} & {$[\mathrm{Ca}]$} & {$[\mathbf{P}]$} & [U] & $\mathbf{U}: \mathbf{P}$ & $\mathrm{U}: \mathrm{Na}$ & U:cation ${ }^{\mathrm{g}}$ \\
\hline $\mathrm{Na}_{2}\left(\mathrm{UO}_{2}\right)_{2}\left(\mathrm{PO}_{4}\right)_{2} \cdot n \mathrm{H}_{2} \mathrm{O}$ & pure & $2.137 \pm 0.056$ & $455 \pm 125$ & $4.2 \pm 1.2$ & $3.4 \pm 0.9$ & $108 \pm 30$ & $2231 \pm 451$ & $2348 \pm 370$ & $1.1 \pm 0.0$ & $5.3 \pm 0.6$ & $5.0 \pm 1.0$ \\
\hline $13.12 \%$ mass loss $(n=6.5)^{\mathrm{a}}$ & unreacted & $0.452 \pm 0.004$ & $3.9 \pm 3.8$ & $0.7 \pm 0.4$ & $<$ LOD & $3.5 \pm 1.8$ & $19 \pm 10$ & $23 \pm 9$ & $1.2 \pm 0.2$ & $4.4 \pm 0.5$ & $3.3 \pm 0.4$ \\
\hline \multirow[t]{2}{*}{$\mathrm{MW}^{\mathrm{b}}=892.9$} & reacted low & $0.190 \pm 0.013$ & $12 \pm 9$ & $1.9 \pm 1.2$ & $<\mathrm{LOD}$ & $131 \pm 54$ & $23 \pm 1$ & $47 \pm 4$ & $2.0 \pm 0.2$ & $5.2 \pm 3.3$ & $0.6 \pm 0.2$ \\
\hline & reacted high & $0.193 \pm 0.005$ & $1.5 \pm 0.6$ & $1.7 \pm 0.1$ & $1.0 \pm 0.9$ & $21 \pm 2$ & $29 \pm 1$ & $33 \pm 1$ & $1.2 \pm 0.0$ & $26 \pm 13$ & $2.5 \pm 0.4$ \\
\hline Ca-autunite & & & {$[\mathrm{Na}]$} & {$[\mathrm{Mg}]$} & {$[\mathbf{K}]$} & [Ca] & {$[\mathbf{P}]$} & {$[\mathbf{U}]$} & $\mathrm{U}: \mathbf{P}$ & U:Ca & U:cation ${ }^{\mathrm{g}}$ \\
\hline $\mathrm{Ca}\left(\mathrm{UO}_{2}\right)_{2}\left(\mathrm{PO}_{4}\right)_{2} \cdot \mathrm{nH}_{2} \mathrm{O}$ & pure & $2.017 \pm 0.062$ & $86 \pm 42$ & $44 \pm 21$ & $43 \pm 21$ & $1105 \pm 539$ & $2750 \pm 972$ & $2868 \pm 903$ & $1.1 \pm 0.0$ & $2.7 \pm 0.5$ & $5.0 \pm 1.6$ \\
\hline $10.81 \%$ mass loss $(n=5.5)^{\mathrm{a}}$ & unreacted & $0.398 \pm 0.025$ & $4.3 \pm 0.4$ & $0.3 \pm 0.2$ & $2.0 \pm 2.8$ & $30 \pm 2$ & $77 \pm 3$ & $86 \pm 3$ & $1.1 \pm 0.0$ & $2.9 \pm 0.3$ & $4.0 \pm 0.1$ \\
\hline \multirow[t]{2}{*}{$\mathrm{MW}^{\mathrm{b}}=909.1$} & reacted low & $0.127 \pm 0.033$ & $1.5 \pm 1.3$ & $0.4 \pm 0.1$ & $1.2 \pm 1.0$ & $14 \pm 2$ & $26 \pm 3$ & $30 \pm 3$ & $1.2 \pm 0.0$ & $2.3 \pm 0.4$ & $3.4 \pm 1.2$ \\
\hline & reacted high & $0.166 \pm 0.013$ & $2.9 \pm 2.0$ & $0.6 \pm 0.1$ & $2.2 \pm 1.1$ & $14 \pm 2$ & $25 \pm 1$ & $28 \pm 1$ & $1.1 \pm 0.0$ & $2.1 \pm 0.3$ & $2.5 \pm 1.0$ \\
\hline Chernikovite & & & [Na] & {$[\mathrm{Mg}]$} & {$[\mathbf{K}]$} & [Ca] & {$[\mathbf{P}]$} & [U] & $\mathrm{U}: \mathbf{P}$ & & U:cation ${ }^{\mathrm{g}}$ \\
\hline $\begin{array}{l}\left(\mathrm{H}_{3} \mathrm{O}\right)_{2}\left(\mathrm{UO}_{2}\right)_{2}\left(\mathrm{PO}_{4}\right)_{2} \cdot n \mathrm{H}_{2} \mathrm{O} \\
14.11 \% \text { mass loss }(n=7.0)^{\mathrm{a}} \\
\mathrm{MW}^{\mathrm{b}}=894.0\end{array}$ & pure & - & $322 \pm 89$ & $12 \pm 3$ & $321 \pm 89$ & $<\mathrm{LOD}$ & $2154 \pm 340$ & $2601 \pm 410$ & $1.2 \pm 0.2$ & & $4.0 \pm 1.1$ \\
\hline \multirow[t]{4}{*}{ Quartz $^{\mathrm{c}}$} & & & {$[\mathrm{Na}]$} & {$[\mathrm{Mg}]$} & {$[\mathbf{K}]$} & {$[\mathbf{C a}]$} & {$[\mathbf{P}]$} & [U] & & & \\
\hline & unreacted & $0.128 \pm 0.015$ & $6.1 \pm 0.7$ & $1.0 \pm 0.1$ & $1.2 \pm 0.4$ & $18.5 \pm 0.5$ & - & $<$ LOD & & & \\
\hline & reacted low & $0.115 \pm 0.005$ & $1.1 \pm 0.4$ & $0.2 \pm 0.2$ & $0.6 \pm 0.2$ & $3.0 \pm 0.1$ & - & $1.3 \pm 0.4$ & & & \\
\hline & reacted high & $0.132 \pm 0.008$ & $1.3 \pm 0.9$ & $0.5 \pm 0.4$ & $0.7 \pm 0.4$ & $6.2 \pm 0.1$ & - & $0.1 \pm 0.1$ & & & \\
\hline
\end{tabular}

${ }^{a}$ From thermogravimetric analysis (TGA), $n=$ number of $\mathrm{H}_{2} \mathrm{O}$ molecules associated with mass loss at temperature range $20-400^{\circ} \mathrm{C}$ (which corresponds to the full

dehydration water), measurement error $=1 \%$ (i.e., ca. $n \pm 0.5$ for these minerals).

${ }^{\mathrm{b}}$ Molecular weight with $\mathrm{nH}_{2} \mathrm{O}$.

Values reproduced from Reinoso-Maset, et al. ${ }^{4}$

${ }^{\mathrm{d}} \mathrm{SSA}=$ specific surface area from $\mathrm{N}_{2}$-BET measurements (average of $n=2-4$ samples).

${ }^{\mathrm{e}}$ Average concentrations $\left(\mu \mathrm{mol} \mathrm{g}{ }^{-1}\right)$ obtained from acid digestion and ICP-MS measurements $(\mathrm{n}=2-4$ replicated samples); LOD $=$ limit of detection.

${ }^{\mathrm{f}}$ Average molar ratios calculated from element concentrations (in $\mu \mathrm{mol} \mathrm{g} \mathrm{g}^{-1}$ ).

${ }^{g}$ Average of $\mathrm{U}$ to sum of cations ( $\mathrm{Na}, \mathrm{Mg}, \mathrm{K}, \mathrm{Ca}$ ) ratios of replicated measurements, accounting for charge balance ( 1 for $1+$ ions and 0.5 for $2+$ ions). 

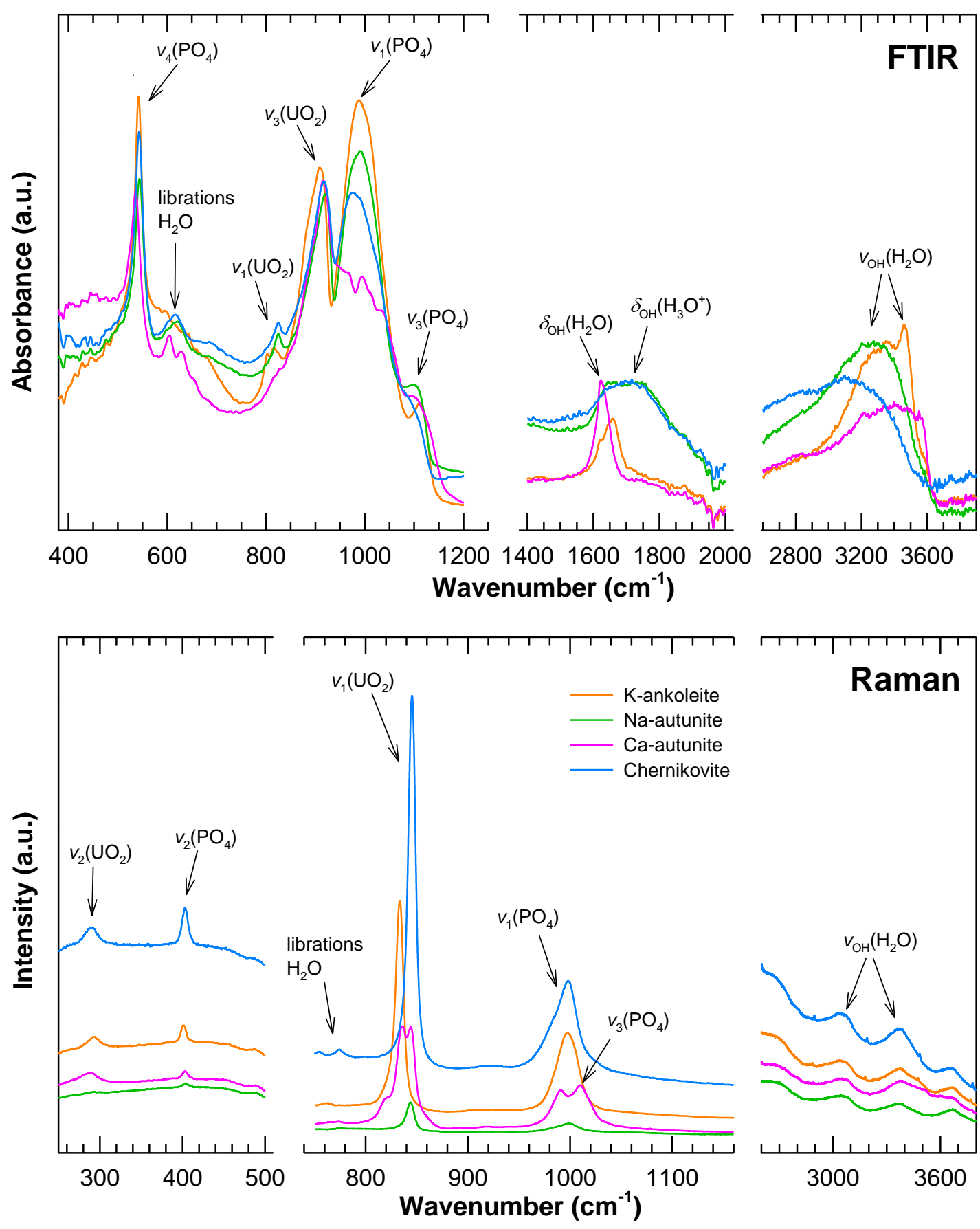

Figure S4. FTIR and Raman spectra in the 400-1200, 1400-2000 and 2600-4000 $\mathrm{cm}^{-1}$, and 250-500, 750-1200 and 2600-3800 $\mathrm{cm}^{-1}$ regions, respectively, for unreacted K-ankoleite, Na-autunite, Caautunite, and chernikovite. Note that the x-axes are broken and y-axes are scaled differently for clarity of the spectral bands. Band assignments are shown in Table S4. 
Table S4. Assignment of vibration bands observed in unreacted K-ankoleite (K-Ank), Na-autunite (Na-Aut), Ca-autunite (Ca-Aut), and chernikovite (Cher) FTIR and Raman spectra (Figure S4). Band identification was based on published FTIR spectra of chernikovite and meta-ankoleite ${ }^{20,}{ }^{21}$ and Raman spectra of phosphuranylite, meta-ankoleite, meta-autunite ${ }^{22,23}$ and $\mathrm{Cu}$ and $\mathrm{Ba}$ uranyl phosphates ${ }^{24,25}$.

\begin{tabular}{|c|c|c|c|c|c|c|c|c|c|}
\hline \multicolumn{5}{|l|}{ FTIR $^{\mathrm{a}}$} & \multicolumn{5}{|l|}{$\operatorname{Raman}^{\mathrm{a}}$} \\
\hline K-Ank & Na-Aut & Ca-Aut & Cher & $\begin{array}{l}\text { Band } \\
\text { assignments }^{\mathrm{b}}\end{array}$ & K-Ank & Na-Aut & Ca-Aut & Cher & $\begin{array}{l}\text { Band } \\
\text { assignments }^{\mathrm{b}}\end{array}$ \\
\hline \multirow[t]{2}{*}{542 (vs) } & 543 (vs) & 536 (vs) & 542 (vs) & $v_{4}\left(\mathrm{PO}_{4}\right)$ & $292(\mathrm{vw})$ & & $289(\mathrm{vw})$ & $290(\mathrm{vw})$ & $v_{2}\left(\mathrm{UO}_{2}\right)$ \\
\hline & $621(w)$ & $\begin{array}{l}604(w) \\
627(w)\end{array}$ & $615(w)$ & $\begin{array}{l}\text { librations } \\
\left(\mathrm{H}_{2} \mathrm{O}\right)\end{array}$ & $400(w)$ & $404(\mathrm{vw})$ & $403(w)$ & $403(\mathrm{~m})$ & $v_{2}\left(\mathrm{PO}_{4}\right)$ \\
\hline $\begin{array}{l}803(w) \\
816(w)\end{array}$ & $825(w)$ & & $825(w)$ & $v_{1}\left(\mathrm{UO}_{2}\right)$ & $763(\mathrm{vw})$ & $774(\mathrm{vw})$ & $773(\mathrm{vw})$ & $\begin{array}{l}755(\mathrm{w}) \\
774(\mathrm{vw})\end{array}$ & $\begin{array}{l}\text { librations } \\
\left(\mathrm{H}_{2} \mathrm{O}\right)\end{array}$ \\
\hline $908(\mathrm{~s})$ & 919 (s) & $915(\mathrm{~s})$ & $917(\mathrm{~s})$ & $v_{3}\left(\mathrm{UO}_{2}\right)$ & 833 (vs) & $844(w)$ & $\begin{array}{l}844(\mathrm{~m}) \\
835(\mathrm{~m}) \\
821(\mathrm{w})\end{array}$ & 845 (vs) & $v_{1}\left(\mathrm{UO}_{2}\right)$ \\
\hline 988 (vs) & 991 (vs) & $\begin{array}{l}965(\mathrm{~m}) \\
994(\mathrm{~m})\end{array}$ & 975 (vs) & $v_{1}\left(\mathrm{PO}_{4}\right)$ & $997(\mathrm{~m})$ & 999 (vw) & $990(\mathrm{~m})$ & $\begin{array}{l}986(\mathrm{w}) \\
998(\mathrm{~m})\end{array}$ & $v_{1}\left(\mathrm{PO}_{4}\right)$ \\
\hline $1110(w)$ & $1094(w)$ & $1093(w)$ & 1091 (vw) & $v_{3}\left(\mathrm{PO}_{4}\right)$ & & & $1009(\mathrm{~m})$ & & $v_{3}\left(\mathrm{PO}_{4}\right)$ \\
\hline \multirow[t]{2}{*}{$1657(\mathrm{~m})$} & & $1621(\mathrm{~m})$ & & $\delta_{\mathrm{OH}}\left(\mathrm{H}_{2} \mathrm{O}\right)$ & $\begin{array}{l}3030(\mathrm{vw}) \\
3374(\mathrm{vw})\end{array}$ & $\begin{array}{l}3046(\mathrm{vw}) \\
3353(\mathrm{vw})\end{array}$ & $\begin{array}{l}3049(\mathrm{vw}) \\
3373(\mathrm{vw})\end{array}$ & $\begin{array}{l}3025(\mathrm{vw}) \\
3361(\mathrm{vw})\end{array}$ & $v_{\mathrm{OH}}\left(\mathrm{H}_{2} \mathrm{O}\right)$ \\
\hline & $1715(\mathrm{w}, \mathrm{b})$ & & $1715(w, b)$ & $\delta_{\mathrm{OH}}\left(\mathrm{H}_{3} \mathrm{O}^{+}\right)$ & & & & & \\
\hline $\begin{array}{l}3348(\mathrm{~m}, \mathrm{~b}) \\
3459(\mathrm{~m})\end{array}$ & $3274(\mathrm{~m}, \mathrm{~b})$ & $3399(\mathrm{~m}, \mathrm{~b})$ & $3094(\mathrm{~m}, \mathrm{~b})$ & $v_{\mathrm{OH}}\left(\mathrm{H}_{2} \mathrm{O}\right)$ & & & & & \\
\hline
\end{tabular}

\footnotetext{
${ }^{\mathrm{a}} \mathrm{s}=$ strong, $\mathrm{m}=$ medium, $\mathrm{w}=$ weak, $\mathrm{v}=$ very, $\mathrm{b}=$ broad

${ }^{\mathrm{b}} v_{1}=$ symmetric stretching, $v_{2}=$ symmetric bending, $v_{3}=$ antisymmetric stretching, $v_{4}=$ antisymmetric bending, $\delta_{\mathrm{OH}}=\mathrm{OH}$ bending, $v_{\mathrm{OH}}=\mathrm{OH}$ stretching
} 


\section{S4.2.2 X-ray Diffraction Before and After Reaction}

X-ray diffractograms of unreacted minerals showed intense and sharp peaks, but with notable differences in peak positions and intensities between the lab- and syn-XRD patterns (Figure 2). This is possibly reflecting slight changes in crystallinity and hydration state of the minerals during storage prior to syn-XRD analysis (as also observed by Kanematsu, et al. ${ }^{19}$ ). While we report and discuss both results in this manuscript, we principally discuss and use the syn-XRD results as they compare more directly with the patterns of reacted minerals.

The X-ray diffractogram of unreacted quartz material (Figure S5a) and quantification (Table S5) matched perfectly the reflections of the quartz-alpha reference pattern. Additionally, published structures (references in Table S5) were used to generate the crystal structures of K-ankoleite, Na-autunite, Ca-autunite, and chernikovite using Crystal Maker (Figure S5b).

Table S5. Quantitative results (in \%) of Rietveld simulations performed on X-ray diffractograms (laband syn-XRD) of K-ankoleite, Na-autunite, Ca-autunite, chernikovite and quartz unreacted and reacted with low and high carbonate background porewater (BPW). See Figure 2 for diffractograms and simulations of mineral samples and Figure S5a for diffractogram patterns of reference minerals.

\begin{tabular}{|c|c|c|c|c|c|c|c|c|}
\hline & \multirow[b]{2}{*}{ Mineral - Sample } & \multicolumn{7}{|c|}{ Reference uranyl mineral phases (in \%)* } \\
\hline & & K-ankoleite & Na-autunite & Ca-autunite & Chernikovite & $\begin{array}{c}\text { Uranyl } \\
\text { phosphate }\end{array}$ & Clarkeite & Quartz- $\alpha$ \\
\hline Fig. $2 A 1$ & unreacted (lab-XRD) & $100.0^{\mathrm{a} 1}$ & & & & & & \\
\hline Fig. $2 A 2$ & unreacted & $100.0^{\mathrm{a} 1}$ & & & & & & \\
\hline & Na-autunite & & & & & & & \\
\hline Fig. $2 \mathrm{D1}$ & unreacted (lab-XRD) & & $100.0^{\mathrm{b} 1}$ & & & & & \\
\hline Fig. 2 D2 & unreacted & & $100.0^{\mathrm{b} 1}$ & & & & & \\
\hline Fig. $2 E$ & reacted low $\mathrm{CO}_{3} \mathrm{BPW}$ & & $40.6^{\mathrm{b} 1}$ & $59.4^{c}$ & & & & \\
\hline Fig. $2 \mathrm{H}$ & reacted low $\mathrm{CO}_{3} \mathrm{BPW}$ & & $74.1^{\mathrm{b} 2}$ & $7.8^{\mathrm{c}}$ & & $17.5^{\mathrm{f}}$ & $0.6^{\mathrm{g}}$ & \\
\hline Fig. $2 I$ & reacted high $\mathrm{CO}_{3} \mathrm{BPW}$ & & $71.0^{\mathrm{b} 2}$ & $17.3^{\mathrm{c}, \mathrm{d}}$ & & $11.3^{\mathrm{f}}$ & $0.4^{\mathrm{g}}$ & \\
\hline & Chernikotive & & & & & & & \\
\hline Fig. $2 \mathrm{~J}$ & unreacted (lab-XRD) & & & & $89.1^{\mathrm{e}}$ & $10.9^{\mathrm{f}}$ & & \\
\hline & Quartz & & & & & & & \\
\hline Fig. S5a & unreacted & & & & & & & 100.0 \\
\hline
\end{tabular}

*Published structures: ${ }^{a 1}$ meta-ankoleite $\left(\mathrm{KUO}_{2} \mathrm{PO}_{4} \cdot 3 \mathrm{D}_{2} \mathrm{O}\right)$ from Fitch and Cole ${ }^{26}$ and ${ }^{\mathrm{a} 2}$ its modified structure with $\mathrm{U}-\mathrm{O}_{\mathrm{ax}}$ distances at 1.67-1.69 $\AA$ instead of 1.76-1.78 $\AA$; ${ }^{\text {b1 }}$ metanatroautunite $\left(\mathrm{Na}\left[\left(\mathrm{UO}_{2}\right)\left(\mathrm{PO}_{4}\right)\right]\left(\mathrm{H}_{2} \mathrm{O}\right)\right)$ from Locock, et al. ${ }^{27} ;{ }^{\text {b2 }}$ metanatroautunite $\left(\mathrm{Na}\left[\left(\mathrm{UO}_{2}\right)\left(\mathrm{PO}_{4}\right)\right]\left(\mathrm{H}_{2} \mathrm{O}\right)_{3}\right)$ from Mills, et al. ${ }^{15}$; ${ }^{\mathrm{c}}$ autunite $\left(\mathrm{Ca}\left[\left(\mathrm{UO}_{2}\right)\left(\mathrm{PO}_{4}\right)\right]_{2}\left(\mathrm{H}_{2} \mathrm{O}\right)_{11}\right)$ from Locock and Burns ${ }^{17}$; ${ }^{\mathrm{d}}$ meta-autunite $\left(\mathrm{Ca}\left(\mathrm{UO}_{2}\right)_{2}\left(\mathrm{PO}_{4}\right)_{2} \cdot 6 \mathrm{H}_{2} \mathrm{O}\right)$ from Makarov and Ivanov ${ }^{28}$; e hydrogen uranyl phosphate tetrahydrate $\left(\mathrm{HUO}_{2} \mathrm{PO}_{4} \cdot 4 \mathrm{H}_{2} \mathrm{O}\right)$ from $\mathrm{Morosin}{ }^{18}$; ${ }_{\mathrm{f}}^{\mathrm{f}}$ trihydrated uranyl bis(dihydrogenophosphate) $\left(\mathrm{UO}_{2}\left(\mathrm{H}_{2} \mathrm{PO}_{4}\right)_{2} \cdot 3 \mathrm{H}_{2} \mathrm{O}\right)$ from Mercier, et al. ${ }^{29}$; and, ${ }^{\mathrm{g}}$ clarkeite $\left(\mathrm{Na}\left[\left(\mathrm{UO}_{2}\right) \mathrm{O}(\mathrm{OH})\right]\left(\mathrm{H}_{2} \mathrm{O}\right)\right)$ from Finch and Ewing ${ }^{30}$. 

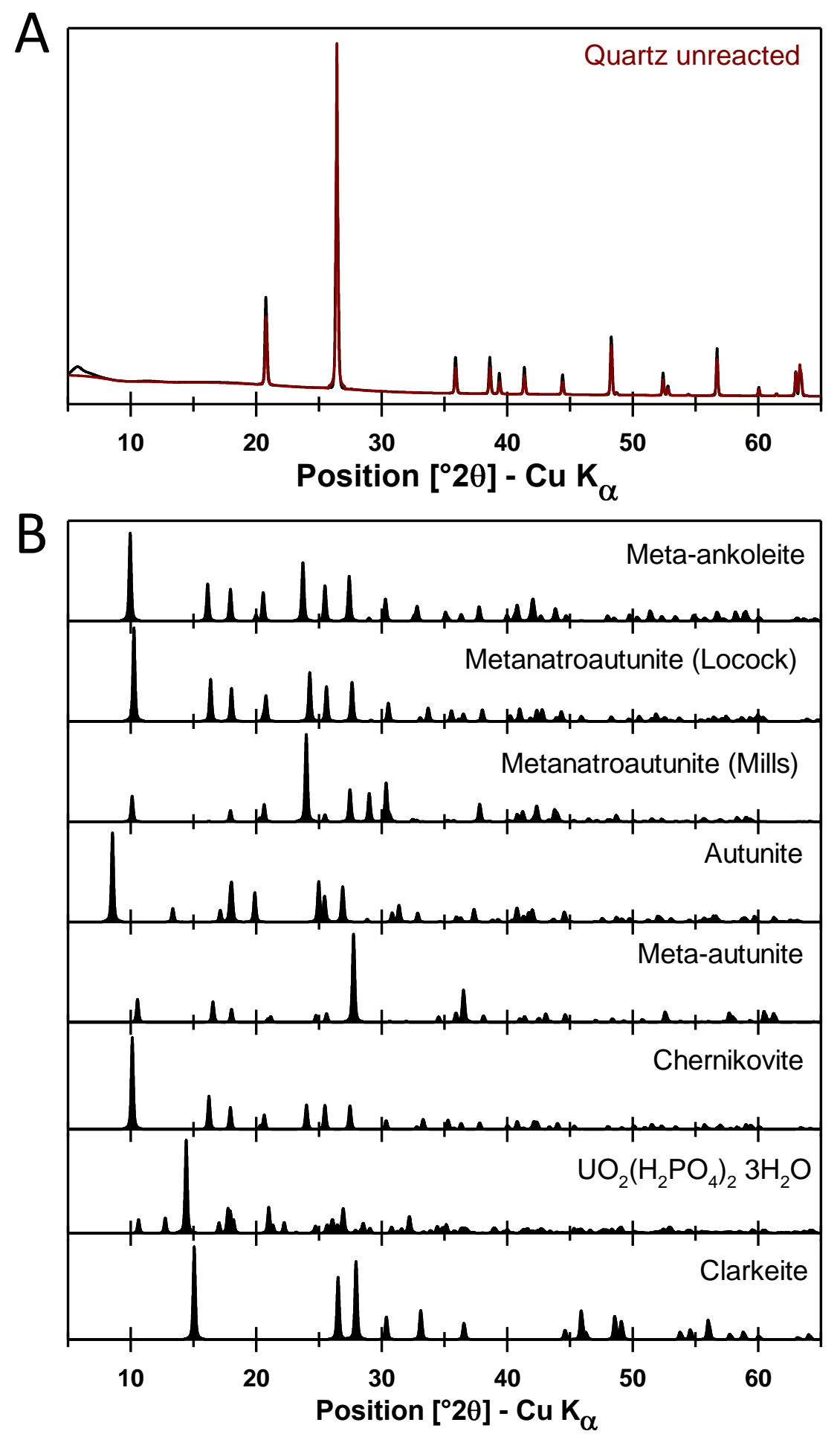

Figure S5a. X-ray diffractograms of quartz and reference minerals: (A) X-ray (black line) and Rietveld simulated (colored line) diffractograms for unreacted quartz, and (B) simulated diffractogram patterns of reference uranyl phosphate minerals (generated from published structures, references in Table S5 footnote) used in Rietveld simulations and quantification performed on X-ray diffractograms (lab- and syn-XRD) of K-ankoleite, Na-autunite, Ca-autunite, and chernikovite (Figure 2, Table S5). 


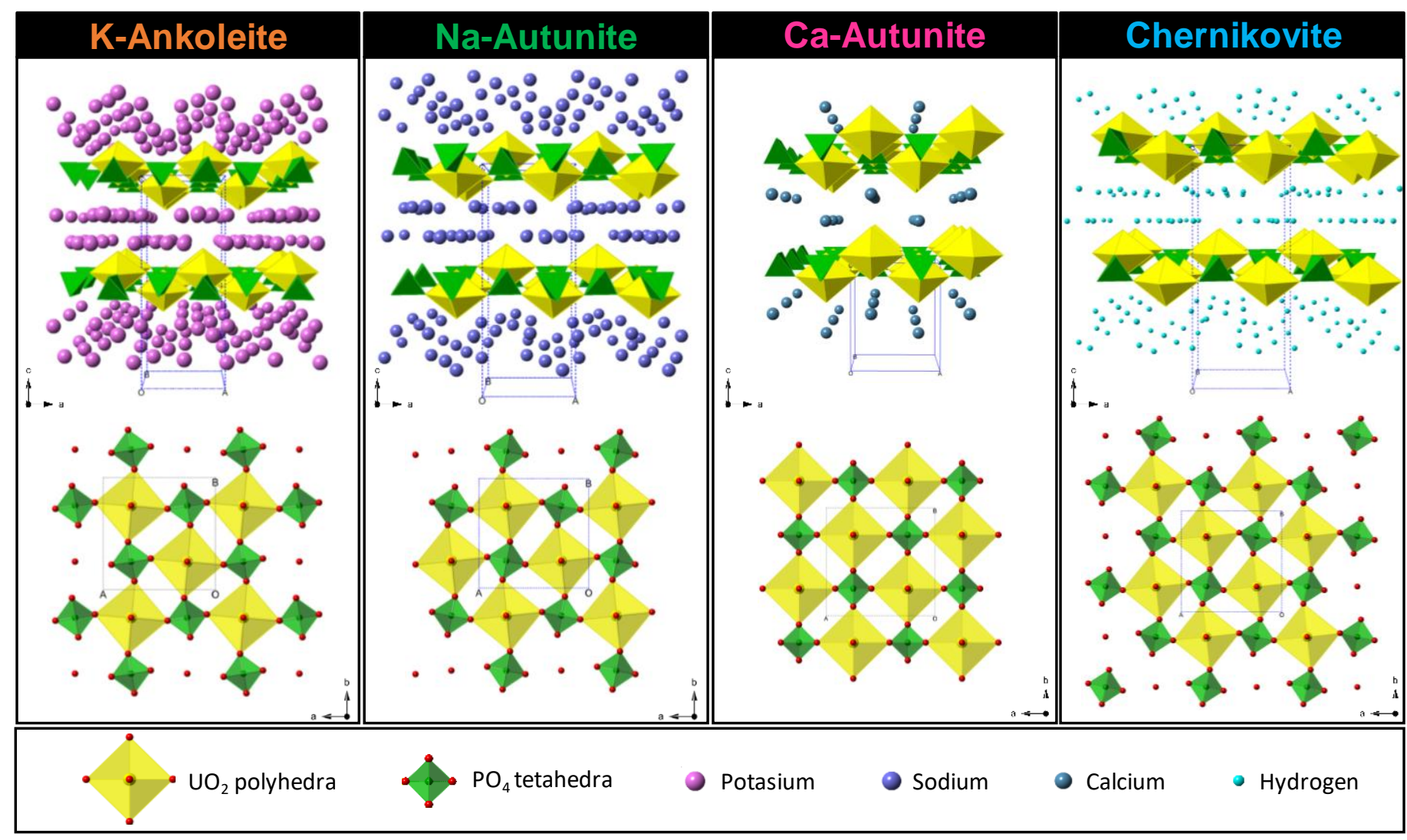

Figure S5b. Crystal structures of uranyl phosphate minerals. Structures were generated with Crystal Maker software based on published structures of meta-ankoleite, metanatroautunite, meta-autunite, and chernikovite (references in Table S5 footnote). 


\section{S4.2.3 X-ray Absorption Spectroscopy Before and After Reaction}

Uranyl phosphate, oxyhydroxide, and silicate compounds are challenging to fit with the shellby-shell approach beyond the first $\mathrm{O}$ shell because of overlapping backscattering wave functions and cancellation effects (see, e.g., Catalano and Brown ${ }^{31}$ and Tayal, et al. ${ }^{32}$ ). Thus, to assess the significance of adding or subtracting shells, the statistical $\mathrm{R}$-factor values from ARTEMIS fits (Tables S6-S7), visual determination, and reasonableness and consistency of the results among all spectra were used in this work as the criteria for selecting the final fits.

Results from EXAFS analysis showed how the local bonding environment around $U$ changed during the dissolution process compared with its initial state in the original mineral. In general, backscattering atoms initially at the same distance in an atomic shell displayed higher static disorder such that shells needed to be split into multiple distances. Yet, all fits were statistically appropriated since a reduced number of adjustable parameters (by applying constrains to the fits) and a maximized information content (by using the maximum k-range and R-range as the data quality allowed) were used. FT resolution $\left(\delta_{R}=0.107 \AA\right)$ was obeyed for all contiguous shells with the same backscattering atoms and the degree of freedom $(v)$ was always $\gg 1$ for all fits $\left(\mathrm{N}_{\text {ind }}=38 ; \mathrm{N}_{\text {fit }}=15\right)$. Statistical estimated standard deviations for individual fitted parameters are given in Tables S6-S7 in parentheses as the uncertainty in the last reported digit(s). Structural results from empirical EXAFS fits of uranyl compounds compared to known crystal structures provide a more conservative estimate of uncertainty. Based on results by Catalano and Brown ${ }^{31}$, estimated error in R distance is: $\mathrm{U}-\mathrm{O}_{\mathrm{ax}} \pm 0.02 \AA$; $\mathrm{U}-\mathrm{O}_{\text {eq }} \pm 0.03 \AA$; U-P $\pm 0.04 \AA$; U-U $\pm 0.02 \AA$. In our fits, either $\mathrm{N}$ or $\sigma^{2}$ was fixed since these parameters are highly correlated. Other EXAFS analyses of uranyl compounds estimated that uncertainty in $\mathrm{N}$ or $\sigma^{2}$ varied from $\sim 15 \%$ for $\mathrm{U}-\mathrm{O}_{\mathrm{ax}}$ to $\sim 50 \%$ for other shells ${ }^{32,33}$.

\section{Unreacted Minerals Shell-by-Shell Fits}

Shell-by-shell fits of the four unreacted mineral spectra (Figure 3 A, D, G, J) based on published crystal structure refinements were very satisfactory (R-factor < 0.0125; Table S6). Axial (2) and equatorial (4) O, P (4) and U (4) shells were grouped in single interatomic distances, which were within +0.014 or $-0.021 \AA$ from reported values. Notably, the U-Oax distances in Na-autunite, Ca-autunite and chernikovite fits were comparable, but $\sim 0.01 \AA$ shorter than K-ankoleite. In all cases, the contribution of multiple scattering (MS) paths for U-O $\mathrm{O}_{\mathrm{ax}}, \mathrm{U}-\mathrm{O}_{\mathrm{eq}}$ and U-P shells was essential for obtaining good fits at $>2.5 \AA$ in the FT (backscattering path deconvolution in Figure S6). 
Table S6. Uranium LIII-edge EXAFS shell-by-shell fits for unreacted K-ankoleite, Na-autunite, Caautunite and chernikovite, and their corresponding published XRD interatomic distances. See Figure 3 for spectra, FT, and associated non-linear least-square fits, and Figure S6 for path deconvolution.

\begin{tabular}{|c|c|c|c|c|c|c|}
\hline \multicolumn{4}{|c|}{ U-L III EXAFS shell-by-shell fits a } & \multicolumn{3}{|c|}{$\mathbf{X R D}^{\mathrm{e}}$} \\
\hline Sample & A-B & $\mathbf{N}^{\mathrm{c}}$ & $\mathbf{R}(\AA)$ & $\sigma^{2}\left(\AA^{2}\right)$ & $\mathbf{N}$ & $\mathbf{R}(\AA)$ \\
\hline (A) K-ankoleite & $\mathrm{U}-\mathrm{O}_{\mathrm{ax}}$ & 2.0 & $1.786(6)$ & $0.0026(4)$ & 2 & $1.761-1.798$ \\
\hline$\left(\mathrm{N}_{\text {Usite }}=1\right)$ & $\mathrm{MSO}_{\mathrm{ax}}{ }^{\mathrm{b} 1}$ & 2.0 & $3.571^{\mathrm{d}}$ & $0.0068(231)$ & 2 & 3.559 \\
\hline$\Delta \mathrm{E}_{0}(\mathrm{eV})=-3.7(1.5)$ & $\mathrm{U}-\mathrm{O}_{\mathrm{eq}}$ & 4.0 & 2.291(7) & $0.0026(4)$ & 4 & $2.226-2.317$ \\
\hline \multirow[t]{4}{*}{$\mathrm{R}$-factor $=0.0086$} & $\mathrm{MSO}_{\mathrm{eq}}{ }^{\mathrm{b} 2}$ & 8.0 & $4.582^{\mathrm{d}}$ & $0.0039(76)$ & 8 & 4.453-4.6150 \\
\hline & U-P & 4.0 & $3.60(2)$ & $0.0035(11)$ & 4 & $3.531-3.639$ \\
\hline & MS P ${ }^{b 3}$ & 8.0 & $3.72^{\mathrm{d}}$ & $0.0015(30)$ & 8 & $3.648-3.756$ \\
\hline & $\mathrm{U}-\mathrm{U}$ & 4.0 & $5.2(2)$ & $0.0050(10)$ & 4 & $5.212-5.249$ \\
\hline (D) Na-autunite & $\mathrm{U}-\mathrm{O}_{\mathrm{ax}}$ & 2.0 & $1.778(6)$ & $0.0024(5)$ & 2 & $1.772-1.799$ \\
\hline$\left(\mathrm{N}_{\text {Usite }}=1\right)$ & $\mathrm{MS} \mathrm{O}_{\mathrm{ax}}^{\mathrm{b} 1}$ & 2.0 & $3.556^{\mathrm{d}}$ & $0.0066(204)$ & 2 & $3.544-3.599$ \\
\hline$\Delta \mathrm{E}_{0}(\mathrm{eV})=-6.5(1.7)$ & $\mathrm{U}-\mathrm{O}_{\mathrm{eq}}$ & 4.0 & $2.304(8)$ & $0.0034(6)$ & 4 & 2.290 \\
\hline \multirow[t]{4}{*}{$\mathrm{R}$-factor $=0.0125$} & $\mathrm{MSO}_{\mathrm{eq}}{ }^{\mathrm{b} 2}$ & 8.0 & $4.608^{\mathrm{d}}$ & $0.0030(60)$ & 8 & 4.580 \\
\hline & U-P & 4.0 & $3.58(1)$ & $0.0027(9)$ & 4 & 3.603 \\
\hline & MS P ${ }^{b 3}$ & 8.0 & $3.69^{\mathrm{d}}$ & $0.0016(31)$ & 8 & 3.715 \\
\hline & $\mathrm{U}-\mathrm{U}$ & 4.0 & $5.24(2)$ & $0.0055(12)$ & 4 & 5.241 \\
\hline (G) Ca-autunite & $\mathrm{U}-\mathrm{O}_{\mathrm{ax}}$ & 2.0 & $1.774(6)$ & $0.0031(5)$ & 2 & $1.783-1.794$ \\
\hline$\left(\mathrm{N}_{\text {Usite }}=1\right)$ & MS Oax ${ }^{b 1}$ & 2.0 & $3.548^{\mathrm{d}}$ & $0.0062(204)$ & 2 & $3.544-3.599$ \\
\hline$\Delta \mathrm{E}_{0}(\mathrm{eV})=-3.3(1.6)$ & $\mathrm{U}-\mathrm{O}_{\mathrm{eq}}$ & 4.0 & $2.296(7)$ & $0.0032(4)$ & 4 & $2.264-2.291$ \\
\hline \multirow[t]{4}{*}{$\mathrm{R}$-factor $=0.0094$} & $\mathrm{MSO}_{\mathrm{eq}}{ }^{\mathrm{b} 2}$ & 8.0 & $4.591^{\mathrm{d}}$ & $0.0030(55)$ & 8 & $4.527-4.563$ \\
\hline & U-P & 4.0 & $3.59(2)$ & $0.0033(15)$ & 4 & $3.585-3.614$ \\
\hline & MS P $\mathrm{P}^{\mathrm{b} 3}$ & 8.0 & $3.69^{\mathrm{d}}$ & $0.0031(37)$ & 8 & $3.684-3.721$ \\
\hline & $\mathrm{U}-\mathrm{U}$ & 4.0 & $5.23(2)$ & $0.0060(14)$ & 4 & $5.234-5.238$ \\
\hline (J) Chernikovite & $\mathrm{U}-\mathrm{O}_{\mathrm{ax}}$ & 2.0 & $1.775(5)$ & $0.0028(4)$ & 2 & $1.750-1.785$ \\
\hline$\left(\mathrm{N}_{\text {Usite }}=1\right)$ & MS Oax ${ }^{b 1}$ & 2.0 & $3.550^{\mathrm{d}}$ & $0.0054(171)$ & 2 & $3.499-3.569$ \\
\hline$\Delta \mathrm{E}_{0}(\mathrm{eV})=-2.9(1.3)$ & $\mathrm{U}-\mathrm{O}_{\mathrm{eq}}$ & 4.0 & $2.307(6)$ & $0.0028(4)$ & 4 & 2.308 \\
\hline \multirow[t]{4}{*}{$\mathrm{R}$-factor $=0.0062$} & $\mathrm{MSO}_{\mathrm{eq}}{ }^{\mathrm{b} 2}$ & 8.0 & $4.615^{\mathrm{d}}$ & $0.0022(46)$ & 8 & 4.616 \\
\hline & U-P & 4.0 & $3.60(1)$ & $0.0033(11)$ & 4 & 3.602 \\
\hline & MS P ${ }^{b 3}$ & 8.0 & $3.71^{\mathrm{d}}$ & $0.0065(61)$ & 8 & 3.714 \\
\hline & $\mathrm{U}-\mathrm{U}$ & 4.0 & $5.23(1)$ & $0.0047(9)$ & 4 & 5.238 \\
\hline
\end{tabular}

${ }^{a} \mathrm{~A}-\mathrm{B}$ is the absorber-backscatterer pair, $\mathrm{N}$ is the coordination number, $\mathrm{R}$ is the interatomic distance in $\AA, \sigma^{2}$ (Debye-Waller factor) is the absorber-backscatterer mean-square relative displacement in $\AA^{2}, \Delta \mathrm{E}_{0}$ is the energy shift in $\mathrm{eV}$ from the leastsquares fit, and R-factor is a goodness-of-fit parameter. The statistical estimated standard deviations for individual fitted parameters are listed in parentheses, representing the uncertainty in the last digit(s).

${ }^{\mathrm{b}}$ Multiple scattering (MS) paths: ${ }^{\mathrm{b} 1} 3$ leg paths: $\mathrm{U} \rightarrow \mathrm{O}_{\mathrm{ax}} \rightarrow \mathrm{U} \rightarrow \mathrm{O}_{\mathrm{ax}}$ and $\mathrm{U} \rightarrow \mathrm{O}_{\mathrm{ax}} \rightarrow \mathrm{U} \rightarrow \mathrm{O}_{\mathrm{ax}}$; ${ }^{\text {b2 }} 4$ leg paths:

$\mathrm{U} \rightarrow \mathrm{O}_{\mathrm{eq}} \rightarrow \mathrm{U} \rightarrow \mathrm{O}_{\mathrm{eq}} \rightarrow \mathrm{U}$ and $\mathrm{U} \rightarrow \mathrm{O}_{\mathrm{eq}} \rightarrow \mathrm{U} \rightarrow \mathrm{O}_{\mathrm{eq}} \rightarrow \mathrm{U}$; ${ }^{\text {b3 }} 3$ leg path: $\mathrm{U} \rightarrow \mathrm{P} \rightarrow \mathrm{O}_{\mathrm{eq}} \rightarrow \mathrm{U}$.

${ }^{\mathrm{c}}$ Parameter fixed or constrained in least-squares fit.

${ }^{\mathrm{d}}$ Parameter linked in the fit to the parameter directly above.

${ }^{\mathrm{e}}$ Interatomic distances calculated from published crystal structure refinements from X-ray diffraction: (i) meta-ankoleite from Cole, et al. ${ }^{16}$, (ii) metanatroautunite from Mills, et al. ${ }^{15}$, (iii) meta-autunite from Locock and Burns ${ }^{17}$, and (iv) chernikovite from Morosin ${ }^{18}$. 
U-L $\mathrm{L}_{\text {III }}$ EXAFS

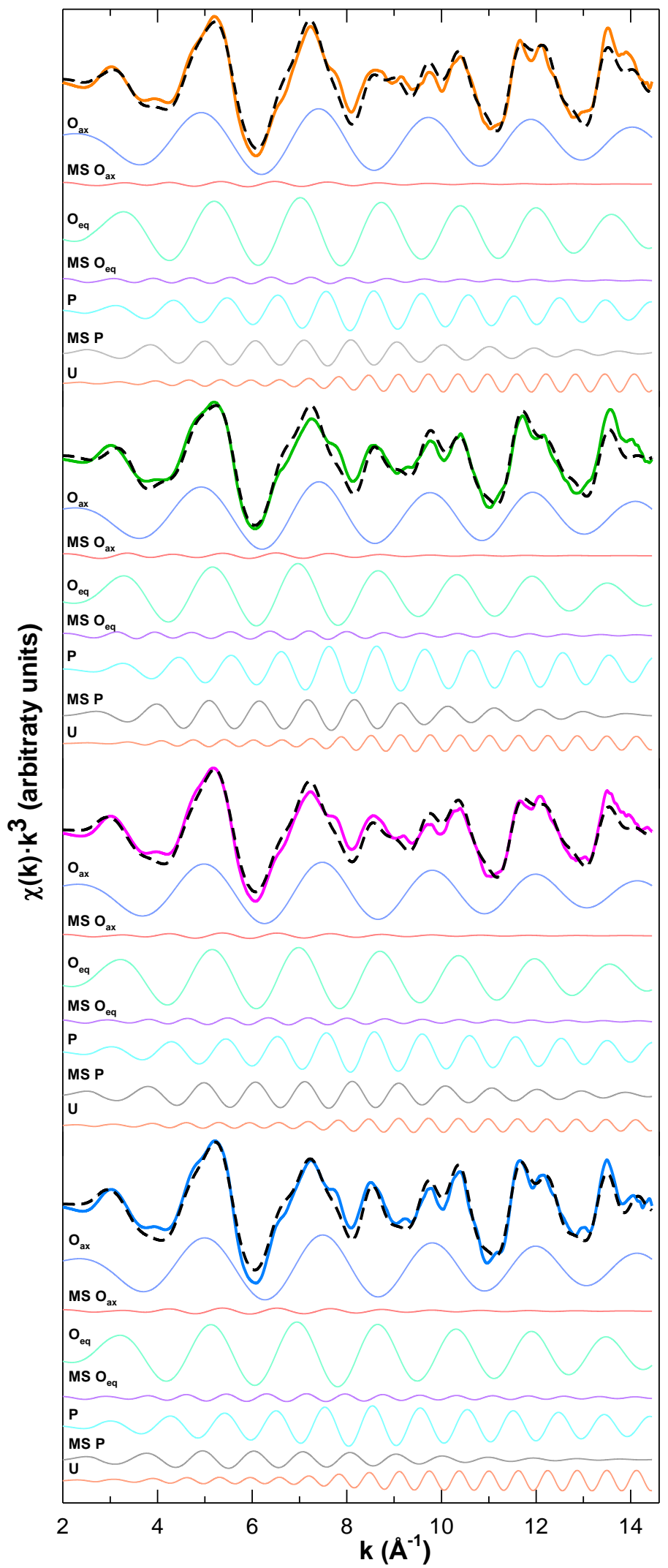

FT

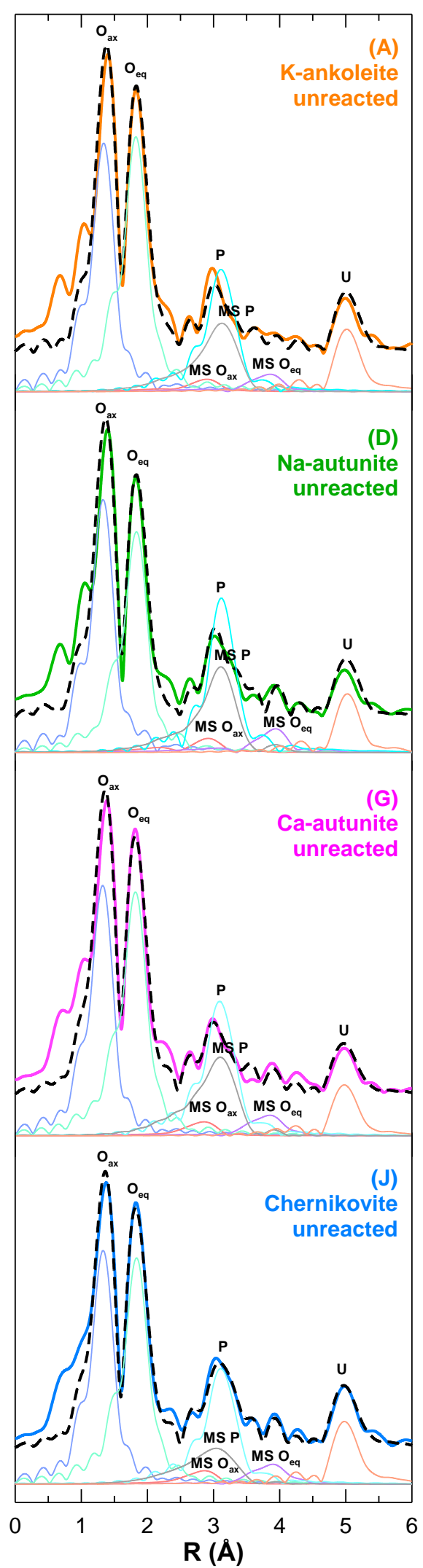

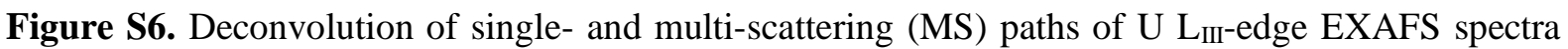
and Fourier Transforms (FT) of the non-linear least-squares shell-by-shell fits for unreacted Kankoleite (A), Na-autunite (D), Ca-autunite $(\mathbf{G})$ and chernikovite $(\mathbf{J})$ presented in Figure 3 and Table S6. Overlapping dashed black lines represent the fits and displaced multi-color lines are the deconvolutions of paths. 


\section{Reacted Minerals Linear Combination and Shell-by-Shell Fits}

Table S7. U L LII-edge EXAFS linear combination and shell-by-shell fits for reacted K-ankoleite, Naautunite and Ca-autunite with low and high carbonate background porewater (BPW). See Figure 3 for EXAFS spectra and FT with the associated non-linear least-square shell-by-shell fits, and Figure S7 for the path deconvolution of the fits. Linear combination results reported in blue are if schoepite is not included in the reference spectra and in pink if only spectra from unreacted minerals spectra are included (see footnote ${ }^{\text {a) }}$.

\begin{tabular}{|c|c|c|c|c|c|c|c|}
\hline \multirow[b]{3}{*}{ Sample } & \multicolumn{7}{|c|}{ U-LIII EXAFS fits } \\
\hline & \multicolumn{2}{|c|}{ Linear combination $^{a}$} & \multicolumn{5}{|l|}{ Shell-by-shell ${ }^{\mathrm{b}}$} \\
\hline & Component & Fraction & & A-B & $\mathbf{N}$ & $\mathbf{R}(\AA)$ & $\sigma^{2}\left(\AA^{2}\right)$ \\
\hline (B) K-ankoleite & K-ankoleite & 0.6240 .6350 .562 & $\Delta \mathrm{E}_{0}(\mathrm{eV})=-3.3(2.5)$ & $\mathrm{U}-\mathrm{O}_{\mathrm{ax}}$ & $2.0^{\mathrm{c}}$ & $1.79(1)$ & $0.0055(8)$ \\
\hline reacted & Ca-autunite & 0.109 & $\mathrm{R}$-factor $=0.0280$ & $\mathrm{U}-\mathrm{O}_{\mathrm{eq}}$ & $0.8(1)$ & $2.21(3)$ & $0.0030^{\mathrm{c}}$ \\
\hline \multirow[t]{6}{*}{ low $\mathrm{CO}_{3} \mathrm{BPW}$} & Schoepite & 0.084 & & $\mathrm{U}-\mathrm{O}_{\mathrm{eq}}$ & $2.5(1)$ & $2.31(1)$ & $0.0030^{\mathrm{c}}$ \\
\hline & Phosphuranylite & 0.047 & & U-P & $2.9(2)$ & $3.54(3)$ & $0.0032^{c}$ \\
\hline & Sum & 0.7080 .6820 .680 & & U-P & $1.0(3)$ & $3.65(4)$ & $0.0032^{c}$ \\
\hline & R-factor $=0.154$ & & & $\operatorname{MS} \mathrm{P}^{\mathrm{d}}$ & $7.2(2)$ & 3.66 & $0.0015^{\mathrm{c}}$ \\
\hline & R-factor $=0.157$ & & & U-U & $3.2(6)$ & $5.20(2)$ & $0.0053^{c}$ \\
\hline & $\mathrm{R}$-factor $=0.158$ & & & U-U & $1.6(6)$ & $5.37(4)$ & $0.0053^{\mathrm{c}}$ \\
\hline (C) K-ankoleite & K-ankoleite & 0.8530 .7760 .668 & $\Delta \mathrm{E}_{0}(\mathrm{eV})=2.7(2.4)$ & $\mathrm{U}-\mathrm{O}_{\mathrm{ax}}$ & $2.0^{\mathrm{c}}$ & $1.821(8)$ & $0.0021(5)$ \\
\hline reacted & Na-autunite & 0.212 & $\mathrm{R}$-factor $=0.0283$ & $\mathrm{U}-\mathrm{O}_{\mathrm{eq}}$ & $3.5(2)$ & $2.318(9)$ & $0.0030^{\mathrm{c}}$ \\
\hline \multirow[t]{9}{*}{ high $\mathrm{CO}_{3} \mathrm{BPW}$} & Schoepite & 0.038 & & $\mathrm{U}-\mathrm{O}_{\mathrm{eq}}$ & $2.1(3)$ & $2.55(2)$ & $0.0030^{c}$ \\
\hline & Meta-ankoleite & 0.105 & & $\mathrm{U}-\mathrm{O}_{\mathrm{eq}}$ & $1.3(4)$ & $2.78(3)$ & $0.0030^{\mathrm{c}}$ \\
\hline & Sum & 0.8910 .8810 .880 & & U-P & $1.7(5)$ & $3.34(2)$ & $0.0032^{c}$ \\
\hline & R-factor $=0.264$ & & & U-P & $3.0(1)$ & $3.59(1)$ & $0.0032^{c}$ \\
\hline & R-factor $=0.264$ & & & U-P & $1.7(9)$ & $3.80(3)$ & $0.0032^{\mathrm{c}}$ \\
\hline & R-factor $=0.263$ & & & U-U & $0.9(4)$ & $3.83(3)$ & $0.0053^{c}$ \\
\hline & & & & $\mathrm{U}-\mathrm{U}$ & $1.3(4)$ & $4.03(3)$ & $0.0053^{c}$ \\
\hline & & & & U-U & $2.1(6)$ & $4.93(3)$ & $0.0053^{c}$ \\
\hline & & & & U-U & $3.8(9)$ & $5.62(3)$ & $0.0053^{\mathrm{c}}$ \\
\hline (E) Na-autunite & K-ankoleite & 0.8210 .464 & $\Delta \mathrm{E}_{0}(\mathrm{eV})=2.4(2.1)$ & $\mathrm{U}-\mathrm{O}_{\mathrm{ax}}$ & $2.0^{c}$ & $1.834(8)$ & $0.0021(5)$ \\
\hline reacted & Na-autunite & 0.7940 .372 & $\mathrm{R}$-factor $=0.0251$ & $\mathrm{U}-\mathrm{O}_{\mathrm{eq}}$ & $3.5(2)$ & $2.325(9)$ & $0.0030^{c}$ \\
\hline \multirow[t]{9}{*}{ low $\mathrm{CO}_{3} \mathrm{BPW}$} & Schoepite & 0.000 & & $\mathrm{U}-\mathrm{O}_{\mathrm{eq}}$ & $2.4(3)$ & $2.55(1)$ & $0.0030^{\mathrm{c}}$ \\
\hline & Meta-ankoleite & 0.046 & & $\mathrm{U}-\mathrm{O}_{\mathrm{eq}}$ & $1.1(4)$ & $2.88(4)$ & $0.0030^{c}$ \\
\hline & Sum & 0.8210 .8400 .836 & & U-P & $1.8(6)$ & $3.37(2)$ & $0.0032^{\mathrm{c}}$ \\
\hline & $\mathrm{R}$-factor $=0.299$ & & & U-P & $2.4(4)$ & $3.62(2)$ & $0.0032^{\mathrm{c}}$ \\
\hline & $\mathrm{R}$-factor $=0.302$ & & & U-P & $1.7(9)$ & $3.81(3)$ & $0.0032^{c}$ \\
\hline & R-factor $=0.294$ & & & $\mathrm{U}-\mathrm{U}$ & $0.9(6)$ & $3.87(4)$ & $0.0053^{c}$ \\
\hline & & & & U-U & $1.8(6)$ & $4.10(2)$ & $0.0053^{c}$ \\
\hline & & & & U-U & $1.3(6)$ & $4.97(6)$ & $0.0053^{c}$ \\
\hline & & & & U-U & $2.1(8)$ & $5.48(4)$ & $0.0053^{c}$ \\
\hline (F) Na-autunite & K-ankoleite & 0.7290 .7270 .690 & $\Delta \mathrm{E}_{0}(\mathrm{eV})=1.4(0.8)$ & $\mathrm{U}-\mathrm{O}_{\mathrm{ax}}$ & $2.0^{\mathrm{c}}$ & $1.817(8)$ & $0.0019(6)$ \\
\hline reacted & Na-autunite & 0.147 & R-factor $=0.0298$ & $\mathrm{U}-\mathrm{O}_{\mathrm{eq}}$ & $3.2(2)$ & $2.32(1)$ & $0.0030^{\mathrm{c}}$ \\
\hline \multirow[t]{11}{*}{ high $\mathrm{CO}_{3} \mathrm{BPW}$} & Schoepite & 0.204 & & $\mathrm{U}-\mathrm{O}_{\mathrm{eq}}$ & $2.1(3)$ & $2.54(2)$ & $0.0030^{c}$ \\
\hline & Phosphuranylite & 0.156 & & $\mathrm{U}-\mathrm{O}_{\mathrm{eq}}$ & $0.9(3)$ & $2.79(5)$ & $0.0030^{\mathrm{c}}$ \\
\hline & Sum & 0.9330 .8830 .837 & & U-P & $1.4(4)$ & $3.33(2)$ & $0.0032^{c}$ \\
\hline & $\mathrm{R}$-factor $=0.225$ & & & U-P & $1.0(3)$ & $3.59(4)$ & $0.0032^{c}$ \\
\hline & $\mathrm{R}$-factor $=0.234$ & & & U-P & $0.7(7)$ & $3.81(7)$ & $0.0032^{c}$ \\
\hline & $\mathrm{R}$-factor $=0.239$ & & & U-U & $0.7(3)$ & $3.82(8)$ & $0.0053^{c}$ \\
\hline & & & & U-U & $2.0(4)$ & $4.07(2)$ & $0.0053^{\mathrm{c}}$ \\
\hline & & & & U-U & $1.7(4)$ & $4.26(2)$ & $0.0053^{c}$ \\
\hline & & & & U-U & $1.5(6)$ & $5.36(4)$ & $0.0053^{c}$ \\
\hline & & & & U-U & $2.4(6)$ & $5.61(4)$ & $0.0053^{c}$ \\
\hline & & & & U-U & $2.5(6)$ & $5.83(4)$ & $0.0053^{c}$ \\
\hline
\end{tabular}


Table S7. (Continued)

\begin{tabular}{|c|c|c|c|c|c|c|c|}
\hline \multirow[b]{3}{*}{ Sample } & \multicolumn{7}{|c|}{ U-LIII EXAFS fits } \\
\hline & \multicolumn{2}{|c|}{ Linear combination $^{a}$} & \multicolumn{5}{|l|}{ Shell-by-shell ${ }^{b}$} \\
\hline & Component & Fraction & & A-B & $\mathbf{N}$ & $\mathbf{R}(\AA)$ & $\sigma^{2}\left(\AA^{2}\right)$ \\
\hline \multirow{10}{*}{$\begin{array}{l}\text { (H) } \mathrm{Ca} \text {-autunite } \\
\text { reacted } \\
\text { low } \mathrm{CO}_{3} \mathrm{BPW}\end{array}$} & K-ankoleite & 0.000 & $\Delta \mathrm{E}_{0}(\mathrm{eV})=7.2(1.1)$ & $\mathrm{U}-\mathrm{O}_{\mathrm{ax}}$ & $2.0^{\mathrm{c}}$ & $1.838(8)$ & $0.0012(4)$ \\
\hline & Na-autunite & 0.6820 .7040 .758 & $\mathrm{R}$-factor $=0.0396$ & $\mathrm{U}-\mathrm{O}_{\mathrm{eq}}$ & $2.4(2)$ & $2.33(1)$ & $0.0030^{\mathrm{c}}$ \\
\hline & Schoepite & 0.136 & & $\mathrm{U}-\mathrm{O}_{\mathrm{eq}}$ & $2.0(3)$ & $2.55(2)$ & $0.0030^{c}$ \\
\hline & Phosphuranylite & 0.075 & & $\mathrm{U}-\mathrm{O}_{\mathrm{eq}}$ & $0.8(4)$ & $2.82(5)$ & $0.0030^{c}$ \\
\hline & Sum & 0.8180 .7790 .758 & & U-P & $1.6(6)$ & $3.36(2)$ & $0.0032^{c}$ \\
\hline & $\mathrm{R}$-factor $=0.382$ & & & U-P & $2.4(5)$ & $3.60(2)$ & $0.0032^{c}$ \\
\hline & R-factor $=0.387$ & & & U-P & $1.9(1.2)$ & $3.77(3)$ & $0.0032^{c}$ \\
\hline & $\mathrm{R}$-factor $=0.388$ & & & U-U & $1.4(4)$ & $4.11(3)$ & $0.0053^{c}$ \\
\hline & & & & U-U & $2.0(6)$ & $4.76(2)$ & $0.0053^{c}$ \\
\hline & & & & U-U & $2.5(6)$ & $4.94(2)$ & $0.0053^{\mathrm{c}}$ \\
\hline \multirow{13}{*}{$\begin{array}{l}\text { (I) Ca-autunite } \\
\text { reacted } \\
\text { high } \mathrm{CO}_{3} \mathrm{BPW}\end{array}$} & K-ankoleite & 0.6000 .019 & $\Delta \mathrm{E}_{0}(\mathrm{eV})=1.2(2.2)$ & $\mathrm{U}-\mathrm{O}_{\mathrm{ax}}$ & $2.0^{\mathrm{c}}$ & $1.807(7)$ & $0.0010(4)$ \\
\hline & Na-autunite & 0.5590 .834 & $\mathrm{R}$-factor $=0.0277$ & $\mathrm{U}-\mathrm{O}_{\mathrm{eq}}$ & $3.6(3)$ & $2.32(1)$ & $0.0030^{\mathrm{c}}$ \\
\hline & Schoepite & 0.438 & & $\mathrm{U}-\mathrm{O}_{\mathrm{eq}}$ & $2.4(4)$ & $2.51(2)$ & $0.0030^{\mathrm{c}}$ \\
\hline & Phosphuranylite & 0.411 & & $\mathrm{U}-\mathrm{O}_{\mathrm{eq}}$ & $1.1(4)$ & $2.74(5)$ & $0.0030^{c}$ \\
\hline & Sum & 1.0380 .9700 .853 & & U-P & $0.4(6)$ & $3.24(6)$ & $0.0032^{c}$ \\
\hline & R-factor $=0.265$ & & & U-P & $2.4(5)$ & $3.60(3)$ & $0.0032^{c}$ \\
\hline & R-factor $=0.275$ & & & U-P & $2.1(1.2)$ & $3.76(3)$ & $0.0032^{c}$ \\
\hline & R-factor $=0.302$ & & & U-U & $2.9(4)$ & $4.03(2)$ & $0.0053^{c}$ \\
\hline & & & & U-U & $1.8(5)$ & $4.22(3)$ & $0.0053^{c}$ \\
\hline & & & & U-U & $1.1(6)$ & $4.49(6)$ & $0.0053^{c}$ \\
\hline & & & & U-U & $1.4(6)$ & $5.32(7)$ & $0.0053^{\mathrm{c}}$ \\
\hline & & & & U-U & $3.4(6)$ & $5.55(4)$ & $0.0053^{\mathrm{c}}$ \\
\hline & & & & U-U & $3.4(6)$ & $5.76(4)$ & $0.0053^{c}$ \\
\hline
\end{tabular}

${ }^{a}$ Linear combination fits were performed using reference spectra from this work (K-ankoleite, Na-autunite, Ca-autunite, chernikovite), Kanematsu, et al. ${ }^{19}$ (phosphuranylite, meta-ankoleite, schoepite, uranyl nitrate), and Reinoso-Maset, et al. ${ }^{4}$ (K-compreignacite, Na-compreignacite, becquerelite, uranyl sorbed on quartz).

${ }^{\mathrm{b}} \mathrm{A}-\mathrm{B}$ is the absorber-backscatterer pair, $\mathrm{N}$ is the coordination number, $\mathrm{R}$ is the interatomic distance in $\AA, \sigma^{2}$ (Debye-Waller factor) is the absorber-backscatterer mean-square relative displacement in $\AA^{2}, \Delta \mathrm{E}_{0}$ is the energy shift in eV from the leastsquares fit, and R-factor is a goodness-of-fit parameter. The statistical estimated standard deviations for individual fitted parameters are listed in parentheses, representing the uncertainty in the last digit(s).

${ }^{c}$ Parameter fixed or constrained in least-squares fits; $\sigma^{2}$ are the average of $\sigma^{2}$ obtained for unreacted spectra (Table S6).

${ }^{d}$ Multiple scattering (MS) 3 leg path $\left(\mathrm{U} \rightarrow \mathrm{P} \rightarrow \mathrm{O}_{\mathrm{eq}} \rightarrow \mathrm{U}\right)$; interatomic distance (R) linked in the fit to the single scattering path directly above. 


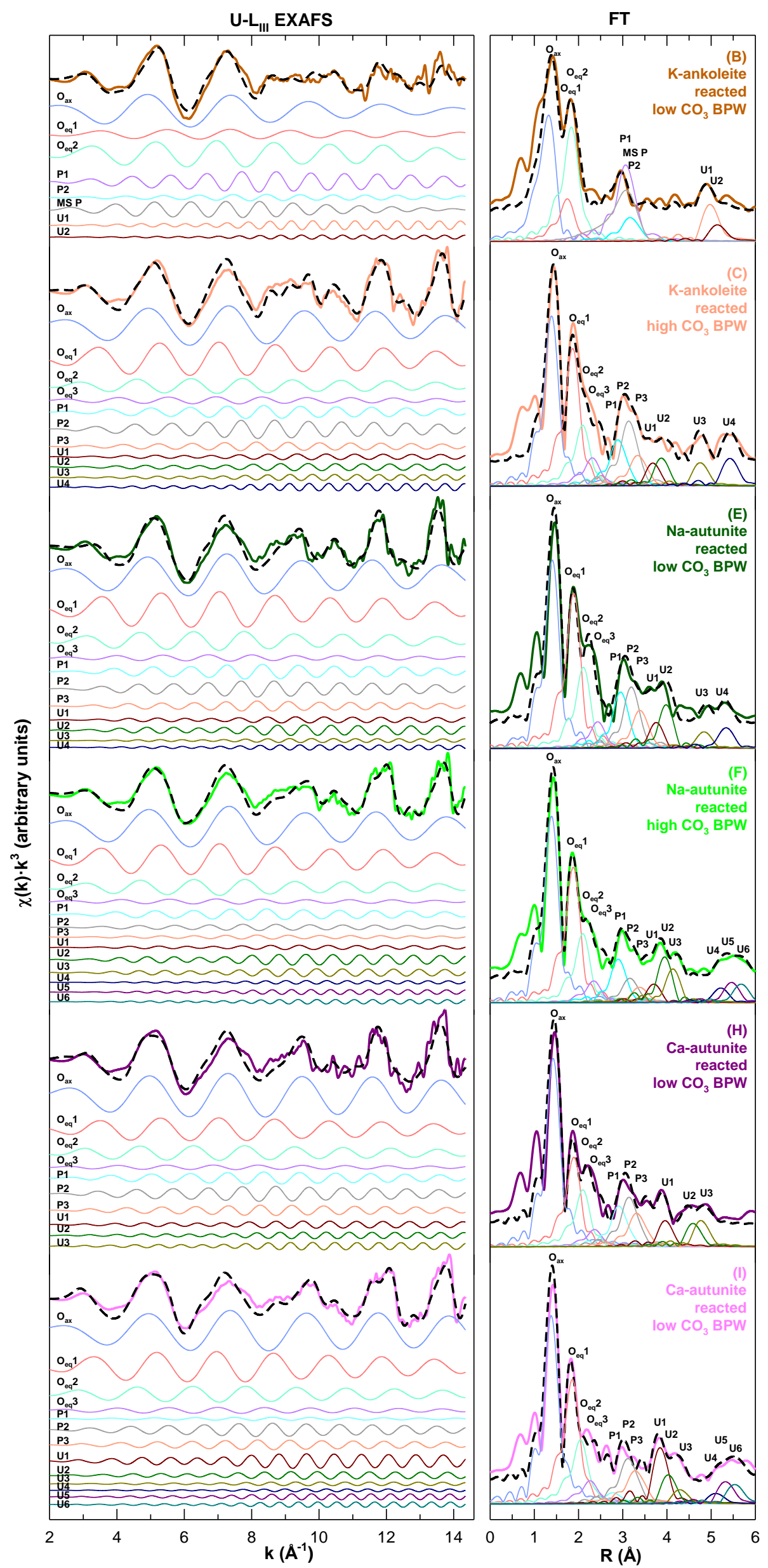

Figure S7. Deconvolution of single- and multi-scattering (MS) paths of $U L_{\mathrm{III}}$-edge EXAFS spectra and Fourier Transforms (FT) of the non-linear least-squares shell-by-shell fits for K-ankoleite (B, C), Na-autunite $(\mathbf{E}, \mathbf{F})$ and Ca-autunite $(\mathbf{H}, \mathbf{I})$ reacted with low and high carbonate BPW presented in Figure 3 and Table S7. Overlapping dashed black lines represent the fits and displaced multi-color lines are the deconvolutions of paths. 


\section{$\underline{\text { S5. Mineral Dissolution Simulations }}$}

\section{S5.1 Reactive Transport Modeling}

CrunchFlow was used in conjunction with the experimental data set to calculate uranyl mineral dissolution rates and release of $U$ under flow conditions following the similar approach as in Reinoso-Maset, et al. ${ }^{4}$. The code CrunchFlow ${ }^{34}$ considers all solid-aqueous phase reactions to be kinetic, and uses rate laws and coefficients included in the database in addition to thermodynamic solubility constants. Thermodynamic constants were obtained from available databases and the literature (Table S8). The transition state theory (TST) rate law was selected for reactive transport simulations to include the thermodynamic mineral solubility of the overall dissolution reaction and the mineral surface area ${ }^{34}$. The general rate law formulation for TST-type precipitation or dissolution reactions $\left(\mathrm{R}_{\mathrm{m}}, \mathrm{mol} \mathrm{m}^{-3}\right.$ porous medium $\mathrm{s}^{-1}$ ) is:

$$
\begin{aligned}
& \mathrm{R}_{\mathrm{m}}=\mathrm{A}_{\mathrm{m}} \mathrm{k}_{\mathrm{m}} \prod a^{n}\left[\left(\frac{\mathrm{Q}_{\mathrm{m}}}{\mathrm{K}_{\mathrm{eq}}}\right)^{\eta}-1\right]^{m} \text { when } \log \left(\mathrm{Q}_{\mathrm{m}} / \mathrm{K}_{\mathrm{eq}}\right)>0 \\
& \mathrm{R}_{\mathrm{m}}=-\mathrm{A}_{\mathrm{m}} \mathrm{k}_{\mathrm{m}} \prod a^{n}\left[\left(\frac{\mathrm{Q}_{\mathrm{m}}}{\mathrm{K}_{\mathrm{eq}}}\right)^{\eta}-1\right]^{m} \text { when } \log \left(\mathrm{Q}_{\mathrm{m}} / \mathrm{K}_{\mathrm{eq}}\right)<0
\end{aligned}
$$

where $\mathrm{A}_{\mathrm{m}}$ is the reactive surface area of a mineral $m\left(\mathrm{~m}^{2}\right.$ mineral $\mathrm{m}^{-3}$ porous media); $\mathrm{k}_{\mathrm{m}}$ is a rate constant $\left(\mathrm{mol} \mathrm{m} \mathrm{m}^{-2} \mathrm{~s}^{-1}\right)$; $\Pi a^{n}$ is a product term for reaction catalysis or inhibition effects far from equilibrium by species in solution with $n$ as the reaction order; and $\left[\left(\mathrm{Q}_{\mathrm{m}}\right.\right.$ $\left.\left./ \mathrm{K}_{\mathrm{eq}}\right)^{\eta}-1\right]^{m}$ is a term for thermodynamic affinity (positive for precipitation, negative for dissolution) considering the ion activity product for the mineral-water reaction $\left(\mathrm{Q}_{\mathrm{m}}\right)$ and the corresponding thermodynamic equilibrium constant $\left(\mathrm{K}_{\mathrm{eq}}\right)$, and with $m$ and $\eta$ as experimentally or theoretical determined exponential dependences.

In this study, no dependence on the concentration of solution species was used (i.e., variables in the term $\Pi a^{n}$ were not included) and the contribution of the thermodynamic affinity term was considered insignificant (experimental conditions were undersaturated with respect to uranyl mineral solubility). Under these conditions, the TST rate law (Eq. S1) is a function of only $\mathrm{A}_{\mathrm{m}}$ and $\mathrm{k}_{\mathrm{m}}$, and the rate constant becomes equivalent to a surface area normalized rate, $\mathrm{R}_{\mathrm{s}}$ in $\mathrm{mol} \mathrm{m} \mathrm{m}^{-2} \mathrm{~s}^{-1}$ (Eq. S2) applied to a congruent, overall mineral dissolution reaction:

$$
\mathrm{R}_{\mathrm{s}}=\mathrm{k}_{\mathrm{m}}=-\frac{\mathrm{R}_{\mathrm{m}}}{\mathrm{A}_{\mathrm{m}}}
$$

The initial $A_{m}$ was calculated following:

$$
A_{m}=\frac{A_{s} \cdot \phi_{m} \cdot M W_{m}}{V_{m}}
$$


where $A_{s}$ is the $N_{2}$-BET specific surface area $\left(\mathrm{m}^{2} \mathrm{~g}^{-1}\right.$; Table $\left.\mathrm{S} 3\right), \phi_{\mathrm{m}}$ is the volume fraction ( $\mathrm{m}^{3}$ mineral $\mathrm{m}^{-3}$ total volume), $\mathrm{MW}_{\mathrm{m}}$ is the molecular weight $\left(\mathrm{g} \mathrm{mol}^{-1}\right)$, and $\mathrm{V}_{\mathrm{m}}$ is the molar volume $\left(\mathrm{m}^{3} \mathrm{~mol}^{-1}\right)$ of the mineral phase $m$.

Initial uranyl minerals volume fraction $\left(\phi_{\mathrm{m}}\right)$ and total column porosity ( $\phi$; Eq. S4) were calculated from the initial mineral mass and volume packed in the columns (Table S2), which then were updated by the code at each time step as a result of mineral mass dissolved and transferred from the solid phase to the aqueous phase. These variations allowed to examine changes in particle size (and thus reactive surface area, $\mathrm{A}_{\mathrm{m}}$ ) with dissolution.

$$
\phi=1-\sum_{m=1}^{N_{m}} \phi_{m}
$$

The linear fluid velocity $(v)$ obtained from fitting $\mathrm{Br}$ tracer breakthrough curves (Table S2, Figure S1) was set as a constant, but the update of porosity $(\phi)$ was allowed to change the volumetric flux $\left(q, \mathrm{~m}^{3} \mathrm{~m}^{-2}\right.$ medium $\left.\mathrm{s}^{-1}\right)$ since $q=\phi \cdot v^{35}$.

These flow and mineral parameters are considered in the mass conservation equation for the transport of solute species in a multicomponent porous medium used by CrunchFlow, which describes the evolution of total concentration of the solute $i, \Psi_{\mathrm{i}}$, as a function of time following the governing differential equation ${ }^{34,35}$ :

$$
\frac{\partial\left(\phi \Psi_{\mathrm{i}}\right)}{\partial \mathrm{t}}=\nabla\left(\phi D^{*} \nabla \Psi_{\mathrm{i}}\right)-\nabla\left(\mathrm{q} \Psi_{\mathrm{i}}\right)-\sum_{\mathrm{m}=1}^{\mathrm{N}_{\mathrm{m}}} \mathrm{v}_{\mathrm{im}} \mathrm{R}_{\mathrm{m}}
$$

where the first two divergence operators $(\nabla)$ involving porosity $(\phi)$, the dispersiondiffusion coefficient $\left(\mathrm{D}^{*}\right)$ and volumetric flux $(q)$ are terms related to the transport through the porous medium, and the last reaction term includes the number of moles of $i$ in each mineral $m\left(v_{i m}\right)$ and the TST mineral dissolution/precipitation rate, $\mathrm{R}_{\mathrm{m}}$.

Therefore, in this work, surface area normalized rates $\left(\mathrm{R}_{\mathrm{s}}\right)$ of uranyl phosphate minerals in low and high carbonate BPW flow-through conditions were calculated by numerical optimization using a Model-Independent Parameter Estimation and Uncertainty Analysis $(\mathrm{PEST})^{36}$ implemented in CrunchFlow to fit the experimental total U concentration in the effluent solution over time ([U $]_{\mathrm{tot}}, \mathrm{mol} \mathrm{L}^{-1}$, as $\Psi_{\mathrm{i}}$ in Eq. S5). The U sorption on quartz was assessed by Reinoso-Maset, et al. ${ }^{4}$ using quartz columns (same material as used in this work) reacted with low carbonate BPW containing dissolved U(VI) (no retention of U was observed in the high carbonate BPW systems). Thus, the estimated surface complexation equilibrium constants (Table S8) were applied in the reactive transport simulations of uranyl phosphate mineral dissolution. 
Table S8. Main thermodynamic solution and solid phase chemical equilibria used in CrunchFlow simulations of uranyl phosphate minerals dissolution in flow-through columns (Figure 1) and estimation of $\log \mathrm{K}_{\mathrm{sp}}$ and $\log \mathrm{R}_{\mathrm{s}}$ (Table 1).

\begin{tabular}{|c|c|c|}
\hline Aqueous chemical equilibria & $\log K$ & Ref. * \\
\hline $\mathrm{H}^{+}+\mathrm{OH}^{-}=\mathrm{H}_{2} \mathrm{O}$ & 13.99 & $a$ \\
\hline $\mathrm{HCl}(\mathrm{aq})=\mathrm{H}^{+}+\mathrm{Cl}^{-}$ & -0.67 & $a$ \\
\hline $\mathrm{HSO}_{4}^{-}=\mathrm{SO}_{4}^{2-}+\mathrm{H}^{+}$ & -1.97 & $a$ \\
\hline $\mathrm{H}_{2} \mathrm{SO}_{4}(\mathrm{aq})=\mathrm{SO}_{4}^{2-}+2 \mathrm{H}^{+}$ & 1.02 & $a$ \\
\hline $\mathrm{PO}_{4}{ }^{3-}+\mathrm{H}^{+}=\mathrm{HPO}_{4}^{2-}$ & 12.32 & $a$ \\
\hline $\mathrm{H}_{2} \mathrm{PO}_{4}^{-}=\mathrm{H}^{+}+\mathrm{HPO}_{4}^{2-}$ & -7.20 & $a$ \\
\hline $\mathrm{H}_{3} \mathrm{PO}_{4}(\mathrm{aq})=2 \mathrm{H}^{+}+\mathrm{HPO}_{4}^{2-}$ & -9.37 & $a$ \\
\hline $\mathrm{P}_{2} \mathrm{O}_{7}^{4-}+\mathrm{H}_{2} \mathrm{O}=2 \mathrm{HPO}_{4}^{2-}$ & 3.74 & $a$ \\
\hline $\mathrm{HP}_{2} \mathrm{O}_{7}^{3-}+\mathrm{H}_{2} \mathrm{O}=\mathrm{H}^{+}+2 \mathrm{HPO}_{4}^{2-}$ & -5.44 & $a$ \\
\hline $\mathrm{H}_{2} \mathrm{P}_{2} \mathrm{O}_{7}^{2-}+\mathrm{H}_{2} \mathrm{O}=2 \mathrm{H}^{+}+2 \mathrm{HPO}_{4}^{2-}$ & -12.07 & $a$ \\
\hline $\mathrm{H}_{3} \mathrm{P}_{2} \mathrm{O}_{7}^{-}+\mathrm{H}_{2} \mathrm{O}=3 \mathrm{H}^{+}+2 \mathrm{HPO}_{4}^{2-}$ & -14.41 & $a$ \\
\hline $\mathrm{H}_{4} \mathrm{P}_{2} \mathrm{O}_{7}(\mathrm{aq})+\mathrm{H}_{2} \mathrm{O}=4 \mathrm{H}^{+}+2 \mathrm{HPO}_{4}^{2-}$ & -15.92 & $a$ \\
\hline $\mathrm{HSiO}_{3}{ }^{-}+\mathrm{H}^{+}=\mathrm{SiO}_{2}(\mathrm{aq})+\mathrm{H}_{2} \mathrm{O}$ & 9.95 & $a$ \\
\hline $\mathrm{H}_{2} \mathrm{SiO}_{4}^{2-}+2 \mathrm{H}^{+}=\mathrm{SiO}_{2}(\mathrm{aq})+2 \mathrm{H}_{2} \mathrm{O}$ & 22.96 & $a$ \\
\hline $\mathrm{H}_{4}\left(\mathrm{H}_{2} \mathrm{SiO}_{4}\right)_{4}^{4-}+4 \mathrm{H}^{+}=4 \mathrm{SiO}_{2}(\mathrm{aq})+8 \mathrm{H}_{2} \mathrm{O}$ & 35.94 & $a$ \\
\hline $\mathrm{H}_{6}\left(\mathrm{H}_{2} \mathrm{SiO}_{4}\right)_{4}{ }^{2-}+2 \mathrm{H}^{+}=4 \mathrm{SiO}_{2}(\mathrm{aq})+8 \mathrm{H}_{2} \mathrm{O}$ & 13.64 & $a$ \\
\hline $\mathrm{CO}_{3}^{2-}+\mathrm{H}^{+}=\mathrm{HCO}_{3}^{-}$ & 10.33 & $a$ \\
\hline $\mathrm{CO}_{2}(\mathrm{aq})+\mathrm{H}_{2} \mathrm{O}=\mathrm{H}^{+}+\mathrm{HCO}_{3}^{-}$ & -6.34 & $a$ \\
\hline $\mathrm{NaOH}(\mathrm{aq})+\mathrm{H}^{+}=\mathrm{Na}^{+}+\mathrm{H}_{2} \mathrm{O}^{-}$ & 14.79 & $a$ \\
\hline $\mathrm{NaCl}(\mathrm{aq})=\mathrm{Na}^{+}+\mathrm{Cl}^{-}$ & 0.77 & $a$ \\
\hline $\mathrm{NaSO}_{4}^{-}=\mathrm{Na}^{+}+\mathrm{SO}_{4}^{2-}$ & -0.82 & $a$ \\
\hline $\mathrm{NaHPO}_{4}^{-}=\mathrm{Na}^{+}+\mathrm{HPO}_{4}^{2-}$ & -0.87 & $b$ \\
\hline $\mathrm{NaH}_{2} \mathrm{PO}_{4}=\mathrm{H}^{+}+\mathrm{Na}^{+}+\mathrm{HPO}_{4}^{2-}$ & -7.62 & $b$ \\
\hline $\mathrm{NaP}_{2} \mathrm{O}_{7}^{3-}+\mathrm{H}_{2} \mathrm{O}=\mathrm{Na}^{+}+2 \mathrm{HPO}_{4}^{2-}$ & 1.45 & $a$ \\
\hline $\mathrm{Na}_{2} \mathrm{P}_{2} \mathrm{O}_{7}^{2-}+\mathrm{H}_{2} \mathrm{O}=2 \mathrm{Na}^{+}+2 \mathrm{HPO}_{4}^{2-}$ & -0.44 & $a$ \\
\hline $\mathrm{NaHP}_{2} \mathrm{O}_{7}^{2-}+\mathrm{H}_{2} \mathrm{O}=\mathrm{H}^{+}+\mathrm{Na}^{+}+2 \mathrm{HPO}_{4}^{2-}$ & -6.84 & $a$ \\
\hline $\mathrm{NaHSiO}_{3}(\mathrm{aq})+\mathrm{H}^{+}=\mathrm{Na}^{+}+\mathrm{SiO}_{2}(\mathrm{aq})+\mathrm{H}_{2} \mathrm{O}$ & 8.30 & $a$ \\
\hline $\mathrm{NaCO}_{3}^{-}+\mathrm{H}^{+}=\mathrm{Na}^{+}+\mathrm{HCO}_{3}^{-}$ & 9.81 & $a$ \\
\hline $\mathrm{NaHCO}_{3}(\mathrm{aq})=\mathrm{Na}^{+}+\mathrm{HCO}_{3}^{-}$ & -0.15 & $a$ \\
\hline $\mathrm{KOH}(\mathrm{aq})+\mathrm{H}^{+}=\mathrm{K}^{+}+\mathrm{H}_{2} \mathrm{O}$ & 14.46 & $a$ \\
\hline $\mathrm{KCl}(\mathrm{aq})=\mathrm{K}^{+}+\mathrm{Cl}^{-}$ & 1.49 & $a$ \\
\hline $\mathrm{KSO}_{4}^{-}=\mathrm{K}^{+}+\mathrm{SO}_{4}^{2-}$ & -0.87 & $a$ \\
\hline $\mathrm{KHSO}_{4}(\mathrm{aq})=\mathrm{H}^{+}+\mathrm{K}^{+}+\mathrm{SO}_{4}^{2-}$ & -0.81 & $a$ \\
\hline $\mathrm{KHPO}_{4}^{-}=\mathrm{K}^{+}+\mathrm{HPO}_{4}^{2-}$ & -0.81 & $b$ \\
\hline $\mathrm{KH}_{2} \mathrm{PO}_{4}^{-}=\mathrm{H}^{+}+\mathrm{K}^{+}+\mathrm{HPO}_{4}^{2}$ & -0.67 & $b$ \\
\hline $\mathrm{KPO}_{4}^{2-}+\mathrm{H}^{+}=\mathrm{K}^{+}+\mathrm{HPO}_{4}^{2}$ & 11.05 & $b$ \\
\hline $\mathrm{KP}_{2} \mathrm{O}_{7}^{3-}+\mathrm{H}_{2} \mathrm{O}=\mathrm{K}^{+}+2 \mathrm{HPO}_{4}^{2-}$ & 1.42 & $a$ \\
\hline $\mathrm{CaOH}^{+}+\mathrm{H}^{+}=\mathrm{Ca}^{2+}+\mathrm{H}_{2} \mathrm{O}$ & 12.85 & $a$ \\
\hline $\mathrm{CaCl}^{+}=\mathrm{Ca}^{2+}+\mathrm{Cl}^{-}$ & 0.69 & $a$ \\
\hline $\mathrm{CaCl}_{2}(\mathrm{aq})=\mathrm{Ca}^{2+}+2 \mathrm{Cl}^{-}$ & 0.64 & $a$ \\
\hline $\mathrm{CaSO}_{4}(\mathrm{aq})=\mathrm{Ca}^{2+}+\mathrm{SO}_{4}{ }^{2-}$ & -2.11 & $a$ \\
\hline
\end{tabular}




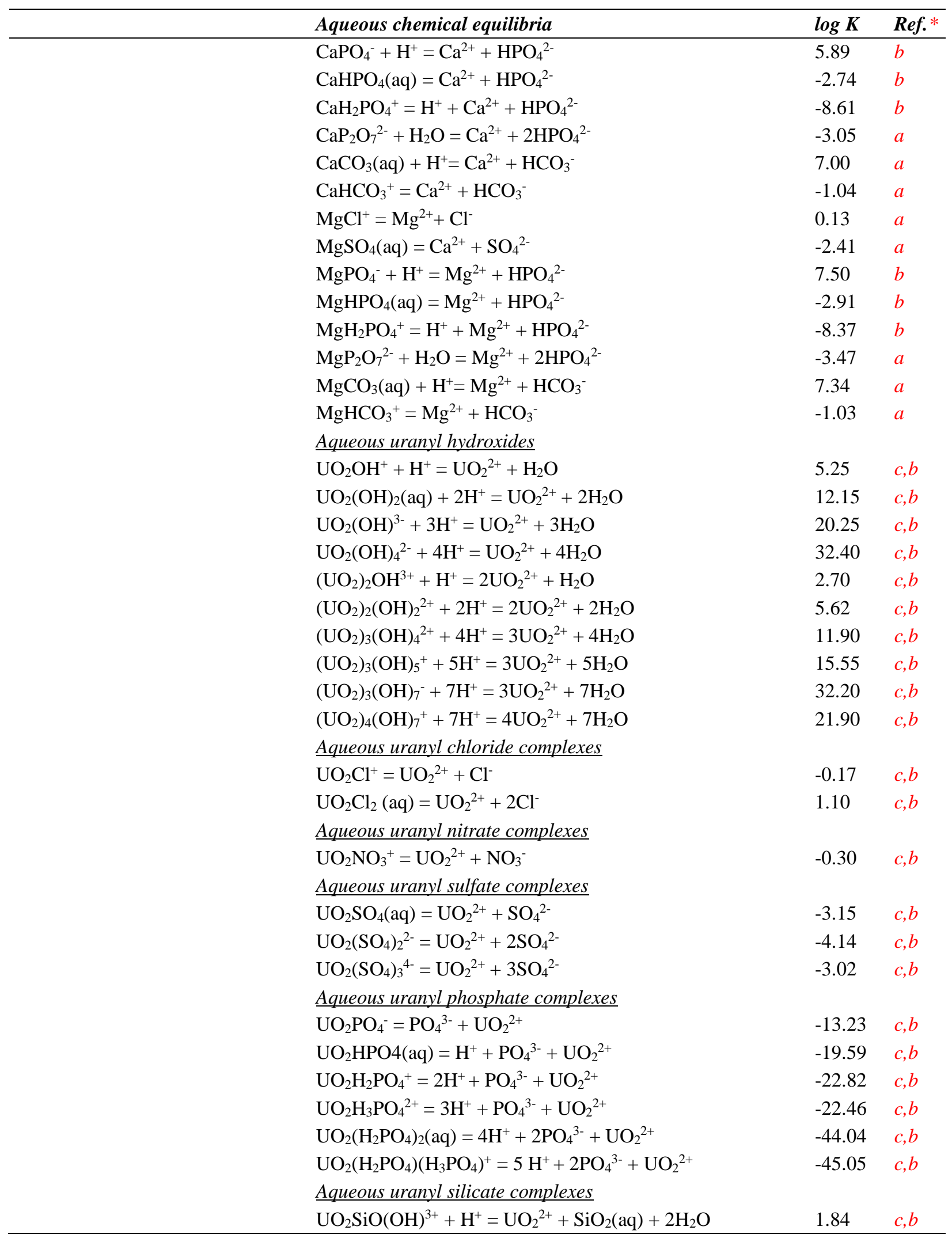




\begin{tabular}{|c|c|c|c|}
\hline & Aqueous chemical equilibria & $\log K$ & Ref. $*$ \\
\hline & \multicolumn{3}{|l|}{ Aqueous uranyl carbonate complexes } \\
\hline & $\mathrm{UO}_{2} \mathrm{CO}_{3}(\mathrm{aq})=\mathrm{UO}_{2}^{2+}+\mathrm{CO}_{3}^{2-}$ & -9.94 & $c, b$ \\
\hline & $\mathrm{UO}_{2}\left(\mathrm{CO}_{3}\right)_{2}{ }^{2-}=\mathrm{UO}_{2}{ }^{2+}+2 \mathrm{CO}_{3}{ }^{2-}$ & -16.61 & $c, b$ \\
\hline & $\mathrm{UO}_{2}\left(\mathrm{CO}_{3}\right)_{3}{ }^{4-}=\mathrm{UO}_{2}^{2+}+3 \mathrm{CO}_{3}^{2-}$ & -21.84 & $c, b$ \\
\hline & $\left(\mathrm{UO}_{2}\right)_{2} \mathrm{CO}_{3}(\mathrm{OH})_{3}{ }^{-}+3 \mathrm{H}^{+}=2 \mathrm{UO}_{2}{ }^{2+}+\mathrm{CO}_{3}{ }^{2-}+3 \mathrm{H}_{2} \mathrm{O}$ & 0.86 & $c, b$ \\
\hline & $\left(\mathrm{UO}_{2}\right)_{3}\left(\mathrm{CO}_{3}\right)_{6}^{6-}=3 \mathrm{UO}_{2}^{2+}+6 \mathrm{CO}_{3}^{2-}$ & -54.00 & $c, b$ \\
\hline & $\left(\mathrm{UO}_{2}\right)_{3} \mathrm{CO}_{3}(\mathrm{OH})_{3}{ }^{+}+3 \mathrm{H}^{+}=3 \mathrm{UO}_{2}^{2+}+\mathrm{CO}_{3}^{2-}+3 \mathrm{H}_{2} \mathrm{O}$ & -0.65 & $c, b$ \\
\hline & $\left(\mathrm{UO}_{2}\right)_{11}\left(\mathrm{CO}_{3}\right)_{6}(\mathrm{OH})_{12^{2-}}+12 \mathrm{H}^{+}=11 \mathrm{UO}_{2}^{2+}+6 \mathrm{CO}_{3}^{2-}+12 \mathrm{H}_{2} \mathrm{O}$ & -36.41 & $c, b$ \\
\hline & \multicolumn{3}{|c|}{ Aqueous ternary uranyl carbonate complexes } \\
\hline & $\mathrm{CaUO}_{2}\left(\mathrm{CO}_{3}\right)_{3}^{2-}=\mathrm{UO}_{2}^{2+}+\mathrm{Ca}^{2+}+3 \mathrm{CO}_{3}^{2-}$ & -27.18 & $d, b$ \\
\hline & $\mathrm{Ca}_{2} \mathrm{UO}_{2}\left(\mathrm{CO}_{3}\right)_{3}{ }^{0}(\mathrm{aq})=\mathrm{UO}_{2}{ }^{2+}+2 \mathrm{Ca}^{2+}+3 \mathrm{CO}_{3}{ }^{2-}$ & -30.70 & $d, b$ \\
\hline & $\mathrm{MgUO}_{2}\left(\mathrm{CO}_{3}\right)_{3}^{2-}=\mathrm{UO}_{2}^{2+}+\mathrm{Mg}^{2+}+3 \mathrm{CO}_{3}^{2-}$ & -26.11 & $d$ \\
\hline & Solid phase equilibria & $\log K_{s p}$ & Ref. $*$ \\
\hline Quartz & $\mathrm{SiO}_{2}(\mathrm{~s})+2 \mathrm{H}_{2} \mathrm{O}=\mathrm{SiO}_{2}(\mathrm{aq})+2 \mathrm{H}_{2} \mathrm{O}$ & -4.63 & $c$ \\
\hline Brushite & $\mathrm{CaHPO}_{4} \cdot 2 \mathrm{H}_{2} \mathrm{O}(\mathrm{s})=\mathrm{Ca}^{2+}+\mathrm{HPO}_{4}^{2-}+\mathrm{H}_{2} \mathrm{O}$ & 6.55 & $a$ \\
\hline Hydroxylapatite & $\mathrm{Ca}_{5}(\mathrm{OH})\left(\mathrm{PO}_{4}\right)_{3}(\mathrm{~s})+4 \mathrm{H}^{+}=5 \mathrm{Ca}^{2+}+3 \mathrm{HPO}_{4}{ }^{2-}+\mathrm{H}_{2} \mathrm{O}$ & -3.07 & $a$ \\
\hline \multirow[t]{2}{*}{ Whitlockite } & $\mathrm{Ca}_{3}\left(\mathrm{PO}_{4}\right)_{2}+2 \mathrm{H}^{+}=3 \mathrm{Ca}^{2+}+2 \mathrm{HPO}_{4}^{2-}$ & -4.22 & $a$ \\
\hline & \multicolumn{3}{|l|}{ Uranyl phosphate minerals } \\
\hline K-autunite & $\mathrm{K}_{2}\left(\mathrm{UO}_{2}\right)_{2}\left(\mathrm{PO}_{4}\right)_{2}(\mathrm{~s})=2 \mathrm{~K}^{+}+2 \mathrm{PO}_{4}^{3-}+2 \mathrm{UO}_{2}{ }^{2+}$ & -48.244 & $e$ \\
\hline Meta-ankoleite & $\mathrm{KUO}_{2} \mathrm{PO}_{4} \cdot 4 \mathrm{H}_{2} \mathrm{O}(\mathrm{s})=\mathrm{K}^{+}+\mathrm{PO}_{4}^{3-}+\mathrm{UO}_{2}{ }^{2+}+4 \mathrm{H}_{2} \mathrm{O}$ & -24.30 & $f$ \\
\hline $\mathrm{KUO} 2 \mathrm{PO} 4(\mathrm{H} 2 \mathrm{O}) 3$ & $\mathrm{KUO}_{2} \mathrm{PO}_{4} \cdot 3 \mathrm{H}_{2} \mathrm{O}(\mathrm{s})=\mathrm{K}^{+}+\mathrm{PO}_{4}{ }^{3-}+\mathrm{UO}_{2}{ }^{2+}+3 \mathrm{H}_{2} \mathrm{O}$ & -26.28 & $g$ \\
\hline KUPO6 $(\mathrm{H} 2 \mathrm{O}) 3$ & $\mathrm{KUPO}_{6} \cdot 3 \mathrm{H}_{2} \mathrm{O}(\mathrm{s})=\mathrm{K}^{+}+\mathrm{PO}_{4}^{3-}+\mathrm{UO}_{2}^{2+}+3 \mathrm{H}_{2} \mathrm{O}$ & -26.47 & $h$ \\
\hline Na-autunite & $\mathrm{Na}_{2}\left(\mathrm{UO}_{2}\right)_{2}\left(\mathrm{PO}_{4}\right)_{2}(\mathrm{~s})=2 \mathrm{Na}^{+}+2 \mathrm{PO}_{4}^{3-}+2 \mathrm{UO}_{2}^{2+}$ & -47.409 & $e$ \\
\hline $\mathrm{NaUO} 2 \mathrm{PO} 4(\mathrm{H} 2 \mathrm{O}) 3$ & $\mathrm{NaUO}_{2} \mathrm{PO}_{4} \cdot 3 \mathrm{H}_{2} \mathrm{O}(\mathrm{s})=\mathrm{Na}^{+}+\mathrm{PO}_{4}{ }^{3-}+\mathrm{UO}_{2}^{2+}+3 \mathrm{H}_{2} \mathrm{O}$ & -24.21 & $i$ \\
\hline $\mathrm{NaUPO6}(\mathrm{H} 2 \mathrm{O}) 3$ & $\mathrm{NaUPO}_{6} \cdot 3 \mathrm{H}_{2} \mathrm{O}(\mathrm{s})=\mathrm{Na}^{+}+\mathrm{PO}_{4}^{3-}+\mathrm{UO}_{2}^{2+}+3 \mathrm{H}_{2} \mathrm{O}$ & -26.19 & $h$ \\
\hline $\mathrm{NaUO} 2 \mathrm{PO} 4(\mathrm{H} 2 \mathrm{O}) x$ & $\mathrm{NaUO}_{2} \mathrm{PO}_{4} \cdot \mathrm{xH}_{2} \mathrm{O}(\mathrm{s})=\mathrm{Na}^{+}+\mathrm{PO}_{4}^{3-}+\mathrm{UO}_{2}^{2+}+\mathrm{xH}_{2} \mathrm{O}$ & -23.64 & $j$ \\
\hline Autunite & $\mathrm{Ca}\left(\mathrm{UO}_{2}\right)_{2}\left(\mathrm{PO}_{4}\right)_{2} \cdot 3 \mathrm{H}_{2} \mathrm{O}(\mathrm{s})=\mathrm{Ca}^{2+}+2 \mathrm{PO}_{4}^{3-}+2 \mathrm{UO}_{2}^{2+}+3 \mathrm{H}_{2} \mathrm{O}$ & -48.36 & $k$ \\
\hline Saleeite & $\mathrm{Mg}\left(\mathrm{UO}_{2}\right)_{2}\left(\mathrm{PO}_{4}\right)_{2}=\mathrm{Mg}^{2+}+2 \mathrm{PO}_{4}^{3-}+2 \mathrm{UO}_{2}^{2+}$ & -43.646 & $e$ \\
\hline H-Autunite & $(\mathrm{H})_{2}\left(\mathrm{UO}_{2}\right)_{2}\left(\mathrm{PO}_{4}\right)_{2}(\mathrm{~s})=2 \mathrm{H}^{+}+2 \mathrm{PO}_{4}^{3-}+2 \mathrm{UO}_{2}^{2+}$ & -47.931 & $e$ \\
\hline Chernikovite & $\mathrm{UO}_{2} \mathrm{HPO}_{4} \cdot 3 \mathrm{H}_{2} \mathrm{O}(\mathrm{s})=\mathrm{H}^{+}+\mathrm{PO}_{4}^{3-}+\mathrm{UO}_{2}{ }^{2+}+3 \mathrm{H}_{2} \mathrm{O}$ & -22.73 & $f$ \\
\hline Uranyl hydrogen phosphate & $\mathrm{UO}_{2} \mathrm{HPO}_{4} \cdot 3 \mathrm{H}_{2} \mathrm{O}(\mathrm{s})=\mathrm{H}^{+}+\mathrm{PO}_{4}{ }^{3-}+\mathrm{UO}_{2}{ }^{2+}+3 \mathrm{H}_{2} \mathrm{O}$ & -25.52 & $k$ \\
\hline HUPO6 $(\mathrm{H} 2 \mathrm{O}) 4$ & $\mathrm{HUPO}_{6} \cdot 4 \mathrm{H}_{2} \mathrm{O}(\mathrm{s})=\mathrm{H}^{+}+\mathrm{PO}_{4}^{3-}+\mathrm{UO}_{2}^{2+}+4 \mathrm{H}_{2} \mathrm{O}$ & -25.15 & $h$ \\
\hline Uranyl orthophosphate (UOP) & $\left(\mathrm{UO}_{2}\right)_{3}\left(\mathrm{PO}_{4}\right)_{2} \cdot 4 \mathrm{H}_{2} \mathrm{O}(\mathrm{s})=2 \mathrm{PO}_{4}{ }^{3-}+3 \mathrm{UO}_{2}{ }^{2+}+4 \mathrm{H}_{2} \mathrm{O}$ & -49.36 & $k$ \\
\hline$U O 2(P O 3) 2$ & $\mathrm{UO}_{2}\left(\mathrm{PO}_{3}\right)_{2}(\mathrm{~s})+2 \mathrm{H}_{2} \mathrm{O}=2 \mathrm{H}^{+}+2 \mathrm{HPO}_{4}^{2-}+\mathrm{UO}_{2}^{2+}$ & -16.28 & $a$ \\
\hline UO2HPO4 & $\mathrm{UO}_{2} \mathrm{HPO}_{4}(\mathrm{~s})=\mathrm{HPO}_{4}^{2-}+\mathrm{UO}_{2}^{2+}$ & -12.17 & $a$ \\
\hline$(U O 2) 2 P 2 O 7$ & $\left(\mathrm{UO}_{2}\right)_{2} \mathrm{P}_{2} \mathrm{O}_{7}(\mathrm{~s})+\mathrm{H}_{2} \mathrm{O}=2 \mathrm{HPO}_{4}^{2-}+2 \mathrm{UO}_{2}{ }^{2+}$ & -14.68 & $a$ \\
\hline$(\mathrm{UO} 2) 3(\mathrm{PO} 4) 2$ & $\left(\mathrm{UO}_{2}\right)_{3}\left(\mathrm{PO}_{4}\right)_{2}(\mathrm{~s})+2 \mathrm{H}^{+}=2 \mathrm{HPO}_{4}{ }^{2-}+3 \mathrm{UO}_{2}{ }^{2+}$ & -14.02 & $a$ \\
\hline & Surface sorption equilibria & $\log K$ & Ref.* \\
\hline & $>\mathrm{SiO}^{-}+\mathrm{H}^{+}=>\mathrm{SiOH}$ & 7.6 & $l$ \\
\hline & $>\mathrm{SiOH}_{2}^{+}=>\mathrm{SiOH}+\mathrm{H}^{+}$ & 1.6 & $l$ \\
\hline & $(>\mathrm{SiO})_{2} \mathrm{UO}_{2}^{0}+2 \mathrm{H}^{+}=2>\mathrm{SiOH}+\mathrm{UO}_{2}^{2+}$ & 4.2 & $m$ \\
\hline & $(>\mathrm{SiO})_{2} \mathrm{UO}_{2} \mathrm{OH}^{-}+3 \mathrm{H}^{+}=2>\mathrm{SiOH}+\mathrm{UO}_{2}^{2+}+\mathrm{H}_{2} \mathrm{O}$ & 9.5 & $m$ \\
\hline
\end{tabular}

*References: (a) LLNL thermodynamic database thermo.com.V8.R6+ ${ }^{37}$; (b) ANDRA thermodynamic database ThermoChimie ${ }^{38}$; (c) NEA thermochemical database (TDB) ${ }^{39}, 40$; (d) Dong and Brooks ${ }^{41}$; (e) USGS WATEQ4F thermodynamic database ${ }^{42}$; (f) Van Haverbeke, et al. ${ }^{21}$; (g) Pavković, et al. ${ }^{43}$; (h) Chernorukov, et al. ${ }^{44}$; (i) Veselý, et al. ${ }^{45}$; (j) Felmy, et al. ${ }^{46}$; (k) Gorman-Lewis, et al. ${ }^{47}$; (1) Sverjensky and Sahai ${ }^{48}$; (m) Reinoso-Maset, et al. ${ }^{4}$. 

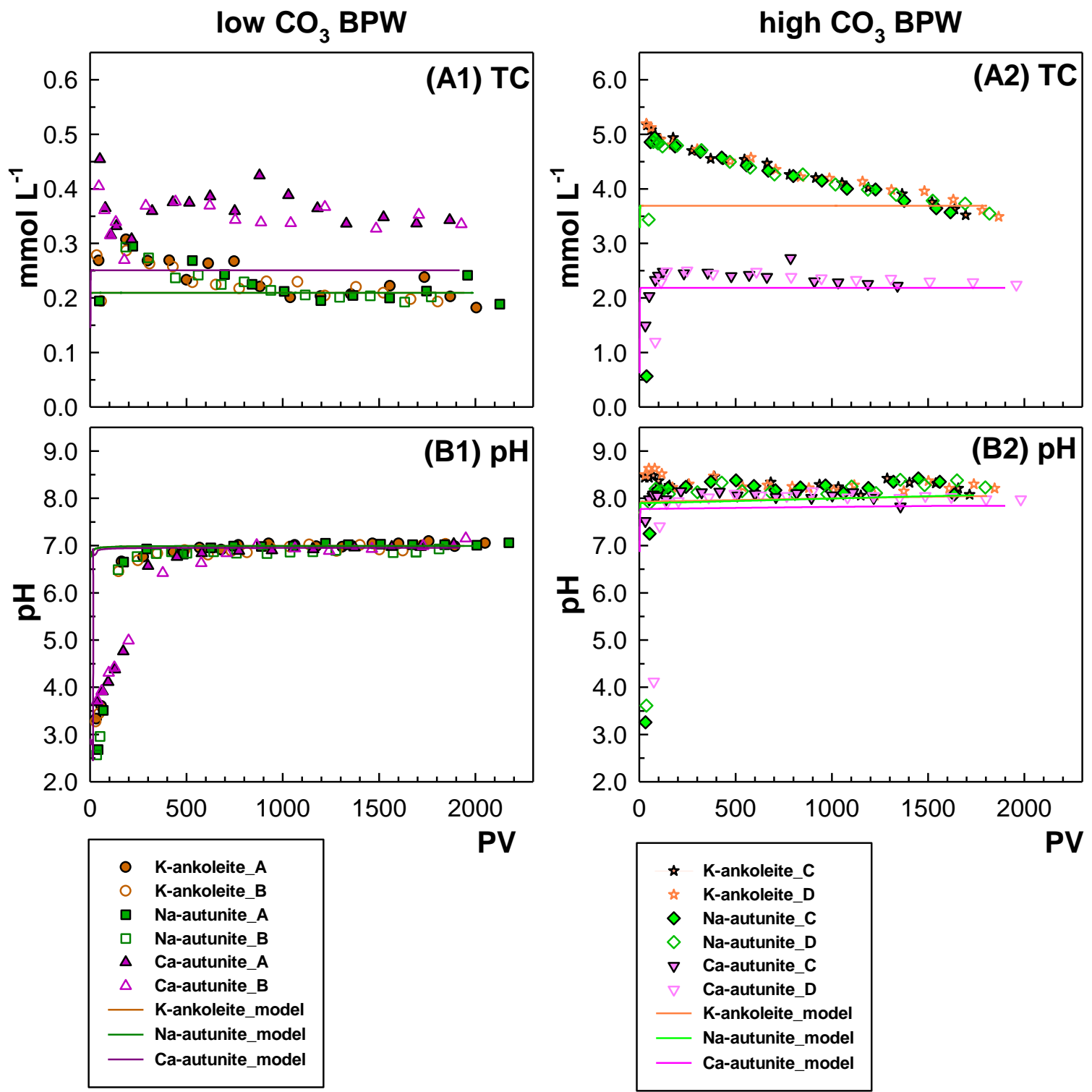

Figure S8. Reactive transport simulation of dissolved total carbon (TC) concentration and $\mathrm{pH}$ measured over time (in pore volumes, PV) for duplicate K-ankoleite (circles/stars), Na-autunite (squares/diamonds), and Ca-autunite (triangles/inverted triangles) flow-through columns reacted with low (A1-B1) and high (A2-B2) carbonate background porewater (BPW). Solid lines represent reactive transport model simulations obtained with CrunchFlow and mineral's solubility products (log $\mathrm{K}_{\mathrm{sp}}$; low carbonate BPW systems) or optimized dissolution rates ( $\log \mathrm{R}_{\mathrm{s}}$; high carbonate BPW systems) reported in Table 1. Note the one order-of-magnitude difference in TC concentration between low and high carbonate BPW conditions. 


\section{$\underline{\text { References }}$}

(1) Wellman, D. M.; Catalano, J. G.; Icenhower, J. P.; Gamerdinger, A. P., Synthesis and characterization of sodium metaautunite, $\mathrm{Na}[\mathrm{UO} 2 \mathrm{PO} 4] \cdot 3 \mathrm{H} 2 \mathrm{O}$. Radiochim. Acta 2005, 93, (7), 393-399.

(2) Gudavalli, R. K. P.; Katsenovich, Y. P.; Wellman, D. M.; Idarraga, M.; Lagos, L. E.; Tansel, B., Comparison of the kinetic rate law parameters for the dissolution of natural and synthetic autunite in the presence of aqueous bicarbonate ions. Chem. Geol. 2013, 351, (0), 299-309.

(3) Thompson, A.; Steefel, C. I.; Perdrial, N.; Chorover, J., Contaminant desorption during long-term leaching of hydroxideweathered Hanford sediments. Environ. Sci. Technol. 2010, 44, (6), 1992-1997.

(4) Reinoso-Maset, E.; Steefel, C. I.; Um, W.; Chorover, J.; O'Day, P. A., Rates and mechanisms of uranyl oxyhydroxide mineral dissolution. Geochim. Cosmochim. Acta 2017, 207, 298-321.

(5) Runkel, R. L., Solution of the advection-dispersion equation: Continuous load of finite duration. J. Environ. Eng. 1996, 122, (9), 830-832.

(6) Rasband, W. S. ImageJ, https://imagej.nih.gov/ij/; U.S. National Institutes of Health: Bethesda, Maryland, USA, $1997-2016$.

(7) Lande, J.; Webb, S. M.; Mehta, A. Area Diffraction Machine, https://github.com/joshualande/AreaDiffractionMachine; 2007.

(8) ICDD, Powder Difraction Files. International Centre for Difraction Data: Newtown Square, PA, 1998.

(9) Downs, R. T.; Hall-Wallace, M., The American Mineralogist crystal structure database. Am. Mineral. 2003, 88, (1), $247-250$.

(10) Gražulis, S.; Daškevič, A.; Merkys, A.; Chateigner, D.; Lutterotti, L.; Quirós, M.; Serebryanaya, N. R.; Moeck, P.; Downs, R. T.; Le Bail, A., Crystallography Open Database (COD): an open-access collection of crystal structures and platform for world-wide collaboration. Nucleic Acids Res. 2012, 40, (D1), D420-D427.

(11) Grazulis, S.; Chateigner, D.; Downs, R. T.; Yokochi, A. F. T.; Quiros, M.; Lutterotti, L.; Manakova, E.; Butkus, J.; Moeck, P.; Le Bail, A., Crystallography Open Database - an open-access collection of crystal structures. J. Appl. Crystallogr. 2009, 42, (4), 726-729.

(12) Perdrial, N.; Rivera, N.; Thompson, A.; O’Day, P. A.; Chorover, J., Trace contaminant concentration affects mineral transformation and pollutant fate in hydroxide-weathered Hanford sediments. J. Hazard. Mater. 2011, 197, (0), 119-127.

(13) Webb, S. M., SIXpack: a graphical user interface for XAS analysis using IFEFFIT. Phys. Scr. 2005, 2005, (T115), 1011.

(14) Ravel, B.; Newville, M., ATHENA, ARTEMIS, HEPHAESTUS: data analysis for X-ray absorption spectroscopy using IFEFFIT. J. Synchrotron Radiat. 2005, 12, (4), 537-541.

(15) Mills, S. J.; Kampf, A. R.; Birch, W. D., The crystal structure of metanatroautunite, $\mathrm{Na}\left[\left(\mathrm{UO}_{2}\right)\left(\mathrm{PO}_{4}\right)\right]\left(\mathrm{H}_{2} \mathrm{O}\right)_{3}$, from the Lake Boga Granite, Victoria, Australia. Am. Mineral. 2012, 97, (4), 735-738.

(16) Cole, M.; Fitch, A. N.; Prince, E., Low-temperature structure of $\mathrm{KUO}_{2} \mathrm{PO}_{4} .3 \mathrm{D}_{2} \mathrm{O}$ determined from combined synchrotron radiation and neutron powder diffraction measurements. J. Mater. Chem. 1993, 3, (5), 519-522.

(17) Locock, A. J.; Burns, P. C., The crystal structure of synthetic autunite, $\mathrm{Ca}\left[\left(\mathrm{UO}_{2}\right)\left(\mathrm{PO}_{4}\right)\right]_{2}\left(\mathrm{H}_{2} \mathrm{O}\right)_{11}$. Am. Mineral. 2003, 88, (1), 240-244.

(18) Morosin, B., Hydrogen uranyl phosphate tetrahydrate, a hydrogen ion solid electrolyte. Acta Crystallographica Section B 1978, 34, (12), 3732-3734.

(19) Kanematsu, M.; Perdrial, N.; Um, W.; Chorover, J.; O’Day, P. A., Influence of phosphate and silica on U(VI) precipitation from acidic and neutralized wastewaters. Environ. Sci. Technol. 2014, 48, (11), 6097-6106.

(20) Clavier, N.; Crétaz, F.; Szenknect, S.; Mesbah, A.; Poinssot, C.; Descostes, M.; Dacheux, N., Vibrational spectroscopy of synthetic analogues of ankoleite, chernikovite and intermediate solid solution. Spectrochimica Acta Part A: Molecular and Biomolecular Spectroscopy 2016, 156, 143-150.

(21) Van Haverbeke, L.; Vochten, R.; Van Springel, K., Solubility and spectrochemical characteristics of synthetic chernikovite and meta-ankoleite. Mineral. Mag. 1996, 60, (5), 759-766.

(22) Frost, R. L.; Čejka, J.; Ayoko, G., Raman spectroscopic study of the uranyl phosphate minerals phosphuranylite and yingjiangite. J. Raman Spectrosc. 2008, 39, (4), 495-502.

(23) Morris, D. E.; Allen, P. G.; Berg, J. M.; Chisholm-Brause, C. J.; Conradson, S. D.; Donohoe, R. J.; Hess, N. J.; Musgrave, J. A.; Tait, C. D., Speciation of uranium in Fernald soils by molecular spectroscopic methods: characterization of untreated soils. Environ. Sci. Technol. 1996, 30, (7), 2322-2331.

(24) Sánchez-Pastor, N.; Pinto, A. J.; Astilleros, J. M.; Fernández-Díaz, L.; Gonçalves, M. A., Raman spectroscopic characterization of a synthetic, non-stoichiometric $\mathrm{Cu}-\mathrm{Ba}$ uranyl phosphate. Spectrochimica Acta Part A: Molecular and Biomolecular Spectroscopy 2013, 113, 196-202. 
(25) Frost, R. L.; Čejka, J.; Ayoko, G. A.; Weier, M., A Raman spectroscopic study of the uranyl phosphate mineral bergenite. Spectrochimica Acta Part A: Molecular and Biomolecular Spectroscopy 2007, 66, (4-5), 979-984.

(26) Fitch, A. N.; Cole, M., The structure of KUO2PO4.3D2O refined from neutron and synchrotron-radiation powder diffraction data. Mater. Res. Bull. 1991, 26, (5), 407-414.

(27) Locock, A. J.; Burns, P. C.; Duke, M. J. M.; Flynn, T. M., Monovalent cations in structures of the meta-autunite group. Can. Mineral. 2004, 42, (4), 973-996.

(28) Makarov, E. S.; Ivanov, V. I., The crystal structure of meta-autunite, Ca(UO2)2(PO4)2*6H2O. Doklady Akademii Nauk SSSR 1960, 132, 601-603.

(29) Mercier, R.; Pham Thi, M.; Colomban, P., Structure, vibrational study and conductivity of the trihydrated uranyl bis(dihydrogenophosphate): UO2(H2PO4)2·3H2O. Solid State Ionics 1985, 15, (2), 113-126.

(30) Finch, R. J.; Ewing, R. C., Clarkeite; new chemical and structural data. Am. Mineral. 1997, 82, (5-6), 607-619.

(31) Catalano, J. G.; Brown, G. E., Analysis of uranyl-bearing phases by EXAFS spectroscopy: Interferences, multiple scattering, accuracy of structural parameters, and spectral differences. Am. Mineral. 2004, 89, (7), 1004-1021.

(32) Tayal, A.; Conradson, S. D.; Kanzari, A.; Lahrouch, F.; Descostes, M.; Gerard, M., Uranium speciation in weathered granitic waste rock piles: an XAFS investigation. RSC Advances 2019, 9, (21), 11762-11773.

(33) Allen, P. G.; Shuh, D. K.; Bucher, J. J.; Edelstein N, M.; Palmer, C. E. A.; Silva, R. J.; Nguyen, S. N.; Marquez, L. N.; Hudson, E. A., Determinations of uranium structures by EXAFS: schoepite and other U(VI) oxide precipitates. In Radiochim. Acta, 1996; Vol. 75, p 47.

(34) Steefel, C. I.; Appelo, C. A. J.; Arora, B.; Jacques, D.; Kalbacher, T.; Kolditz, O.; Lagneau, V.; Lichtner, P. C.; Mayer, K. U.; Meeussen, J. C. L.; Molins, S.; Moulton, D.; Shao, H.; Šimůnek, J.; Spycher, N.; Yabusaki, S. B.; Yeh, G. T., Reactive transport codes for subsurface environmental simulation. Computat. Geosci. 2015, 19, (3), 445-478.

(35) Lichtner, P. C., Chapter 1: Continuum formulation of multicomponent-multiphase reactive transport. In Reviews in Mineralogy, volume 34: Reactive transport in porous media, Lichtner, P. C.; Steefel, C. I.; Oelkers, E. H., Eds. Mineralogical Society of America: 1997; pp 1 - 82.

(36) Doherty, J., Calibration and uncertainty analysis for complex environmental models. Watermark Numerical Computing: Brisbane, Australia, 2015; Vol. PEST: complete theory and what it means for modelling the real world.

(37) Johnson, J.; Anderson, G.; Parkhurst, D. L. LLNL Thermodynamic Database thermo.com.V8.R6+, https://www.gwb.com/thermo.php; Lawrence Livermore National Laboratory: Livermore, CA, 1996.

(38) Giffaut, E.; Grivé, M.; Blanc, P.; Vieillard, P.; Colàs, E.; Gailhanou, H.; Gaboreau, S.; Marty, N.; Madé, B.; Duro, L., Andra thermodynamic database for performance assessment: ThermoChimie. Appl. Geochem. 2014, 49, 225-236.

(39) Grenthe, I.; Fuger, J.; Konings, R. J. M.; Lemire, R. J.; Muller, A. B.; Nguyen-Trung, C.; Wanner, H., Chemical thermodynamics of uranium. Elsevier: Paris, France, 1992; p 715.

(40) Guillaumont, R.; Fanghanel, T.; Neck, V.; Fuger, J.; Palmer, D. A.; Grenthe, I.; Rand, M. H., Update on the chemical thermodynamics of uranium, neptunium, plutonium, americium and technetium. Elsevier: Paris, 2003; p 918.

(41) Dong, W.; Brooks, S. C., Determination of the formation constants of ternary complexes of uranyl and carbonate with alkaline earth metals $\left(\mathrm{Mg}^{2+}, \mathrm{Ca}^{2+}, \mathrm{Sr}^{2+}\right.$, and $\left.\mathrm{Ba}^{2+}\right)$ using anion exchange method. Environ. Sci. Technol. 2006, 40, (15), 46894695.

(42) Ball, J. W.; Nordstrom, D. K. User's manual for WATEQ4F, with revised thermodynamic data base and test cases for calculating speciation of major, trace, and redox elements in natural waters; U.S. Geological Survey: Menlo Park, California, 2001; p 59.

(43) Pavković, N.; Marković, M.; Kojić-Prodić, B., Spontaneous precipitation in the system uranyl(2+ )nitrate potassium hydroxide - phosphoric acid - water. Croat. Chem. Acta 1982, 55, (4), 393-403.

(44) Chernorukov, N. G.; Nipruk, O. V.; Pykhova, Y. P.; Godovanova, N. S., State of uranophosphates MIPUO6·nH2O (MI = $\mathrm{H}+\mathrm{Li}+, \mathrm{Na}+, \mathrm{K}+, \mathrm{Rb}+, \mathrm{Cs}+, \mathrm{NH} 4+$ ) in saturated aqueous solutions. Radiochemistry 2011, 53, (4), 361.

(45) Veselý, V.; Pekárek, V.; Abbrent, M., A study on uranyl phosphates-III solubility products of uranyl hydrogen phosphate, uranyl orthophosphate and some alkali uranyl phosphates. Journal of Inorganic and Nuclear Chemistry 1965, 27, (5), 11591166.

(46) Felmy, A. R.; Xia, Y.; Wang, Z., The solubility product of NaUO2PO4·xH2O determined in phosphate and carbonate solutions. In Radiochim. Acta, 2005; Vol. 93, p 401.

(47) Gorman-Lewis, D.; Shvareva, T.; Kubatko, K.-A.; Burns, P. C.; Wellman, D. M.; McNamara, B.; Szymanowski, J. E. S.; Navrotsky, A.; Fein, J. B., Thermodynamic properties of autunite, uranyl hydrogen phosphate, and uranyl orthophosphate from solubility and calorimetric measurements. Environ. Sci. Technol. 2009, 43, (19), 7416-7422.

(48) Sverjensky, D. A.; Sahai, N., Theoretical prediction of single-site surface-protonation equilibrium constants for oxides and silicates in water. Geochim. Cosmochim. Acta 1996, 60, (20), 3773-3797. 